\title{
In country we trust? National trust and the governance of international R\&D alliances
}

Citation for published version (APA):

Kwon, S-W., Haleblian, J., \& Hagedoorn, J. (2016). In country we trust? National trust and the governance of international R\&D alliances. Journal of International Business Studies, 47(7), 807-829.

https://doi.org/10.1057/s41267-016-0006-3

Document status and date:

Published: 01/09/2016

DOI:

10.1057/s41267-016-0006-3

Document Version:

Accepted author manuscript (Peer reviewed / editorial board version)

\section{Please check the document version of this publication:}

- A submitted manuscript is the version of the article upon submission and before peer-review. There can be important differences between the submitted version and the official published version of record.

People interested in the research are advised to contact the author for the final version of the publication, or visit the DOI to the publisher's website.

- The final author version and the galley proof are versions of the publication after peer review.

- The final published version features the final layout of the paper including the volume, issue and page numbers.

Link to publication

\footnotetext{
General rights rights.

- You may freely distribute the URL identifying the publication in the public portal. please follow below link for the End User Agreement:

www.umlib.nl/taverne-license

Take down policy

If you believe that this document breaches copyright please contact us at:

repository@maastrichtuniversity.nl

providing details and we will investigate your claim.
}

Copyright and moral rights for the publications made accessible in the public portal are retained by the authors and/or other copyright owners and it is a condition of accessing publications that users recognise and abide by the legal requirements associated with these

- Users may download and print one copy of any publication from the public portal for the purpose of private study or research.

- You may not further distribute the material or use it for any profit-making activity or commercial gain

If the publication is distributed under the terms of Article $25 \mathrm{fa}$ of the Dutch Copyright Act, indicated by the "Taverne" license above, 
IN COUNTRY WE TRUST?: NATIONAL TRUST AND THE GOVERNANCE OF INTERNATIONAL R\&D ALLIANCES

\author{
SEOK-WOO KWON \\ Assistant Professor \\ Dept. of Strategic Management \\ Fox School of Business \\ Temple University \\ Philadelphia, PA 19122 \\ Email: kwon@temple.edu \\ Tel. 215-204-8188 \\ JERAYR “JOHN” HALEBLIAN \\ Associate Professor of Management \\ School of Business Administration \\ University of California-Riverside \\ Riverside, CA 92521 \\ JOHN HAGEDOORN \\ Professor of International Business and Strategy \\ School of Management \\ Royal Holloway, University of London \\ Egham, Surrey \\ United Kingdom \\ and \\ UNU-MERIT, Maastricht University \\ P.O. Box 616 \\ 6200 MD Maastricht \\ The Netherlands \\ E-mail: J.Hagedoorn@maastrichtuniversity.nl \\ Running title: In Country We Trust?
}

Acknowledgments

We would like to thank seminar participants at the Rutgers Business School, the University of Kentucky, the University of California at Riverside, Temple University, Maastricht University, Royal Holloway, University of London, the Annual meetings of Academy of Management, the International Sunbelt Social Network Conference, and the following individuals for helpful comments: Paul Adler, Dan Brass, Philip Bromiley, Michael Haselhuhn, Laura Little, David Stewart, Tony Tong, and Elaine Wong. 


\section{IN COUNTRY WE TRUST?: NATIONAL TRUST AND THE GOVERNANCE OF INTERNATIONAL R\&D ALLIANCES}

Drawing on a cognitive perspective of trust, we propose that the trust towards an alliance partner's country, which we call national trust, will affect the governance structure used to organize the alliance between the partners. We further argue that this effect of national trust is moderated by improved information on the partner firm generated both from repeated interactions and the firm's position in an alliance network. Using a sample of international alliances among firms based in Western European countries, we perform several analyses that control for a variety of alternative explanations. We find support for the main effect of national trust on alliance governance decisions, as well as partial support for an information-based moderation such that national trust has lesser influence on governance choices as trust-relevant information on a partner firm increases. 
In the international alliance governance literature, trust defined as “. . . the expectation that the other will perform a particular action important to the truster, irrespective of the ability to monitor or control that other party . ..” (Mayer, Davis, \& Schoorman, 1995: 712), has emerged as a central theme. This literature suggests that higher levels of inter-firm trust should result in more efficient governance. Trust allows alliance partners to relinquish the costly hierarchical control offered by equity forms of governance, in favor of more flexible non-equity alliances (Arikan \& Shenkar, 2013; Bromiley \& Cummings, 1995; Casciaro, 2003; Colombo, 2003; Das \& Teng, 1998; García-Canal, 1996; Globerman \& Nielsen, 2007; Gulati, 1995; Li, Eden, Hitt, \& Ireland, 2008; Oxley, 1997), resulting in gains in efficiency. Most work in this line of trust research has focused on trust arising from prior exchanges between partners (Casciaro, 2003; Gulati, 1995; Li, Eden, Hitt, \& Ireland, 2008; Oxley, 1997; Zaheer, McEvily, \& Perrone, 1998): direct interaction among organizational decision-makers facilitates trust. This interactionbased form of trust building has also been referred to as the history-based view of trust (Kramer, 1999). ${ }^{1}$

Although the history-based view of trust has contributed to our understanding of how trust influences alliance governance, research on social categorization suggests there may be another source of trust. This category-based view of trust argues that identifying individuals or groups as belonging to a particular social category, such as national, ethnic, religious, or political, enables decision-makers to infer trustworthiness (Bodenhausen, Kang, \& Peery, 2012; Foddy \& Yamagishi, 2009; Gambetta \& Hamill, 2005; Guiso, Sapienza, \& Zingales, 2009; Kramer, 1999; McEvily, Weber, Bicchieri, \& Ho, 2006; McKnight, Cummings, \& Chervany, 1998; Meyerson, Weick, \& Kramer, 1996). Perhaps surprisingly, though, few insights from this cognitive categorization perspective have diffused into the literature on trust and governance choices. As a 
result, the current literature does not yet inform us whether, how, and why trust based on category membership may affect the governance mode of inter-organizational alliances.

We investigate whether a firm's decision makers might be influenced by how much trust they place in the national membership of a partner organization, which we refer to as national trust. Because organizational decision makers are experienced in negotiating and launching international alliances, we might expect them to be already sophisticated in dealing with national and cultural biases, and thus unaffected by biases related to national category. However, the few studies that have considered perceived trust toward the home countries of partner firms have shown otherwise. For example, prior work suggests that alliance partners adjust their trust toward alliance counterparts depending on the nationality of the counterpart (Arino, de la Torre, \& Ring, 2001). Similarly, recent research shows that trust between international joint venture partners varies by the home countries of both partners (Ertug, Cuypers, Noorderhaven, \& Bensaou, 2013). However, no prior study has examined whether and how national trust influences the choice of governance mode of international alliances. Therefore, we examine the choices of governance mode (i.e., equity vs contractual) in international R\&D alliances and how they are influenced by national trust among firms based in Western European countries.

Our research has the potential to make two important contributions to the trust literature in international alliances. First, we extend the research on trust in international alliances by showing that home country-based categorization influences not just perceptions of whether alliance partners can be trusted, as demonstrated in a recent paper (Ertug, Cuypers, Noorderhaven, \& Bensaou, 2013), but also influences organizational outcomes in the form of governance choices between alliance partners from differing countries. We thus go beyond the previous finding that national trust influences managerial trust in alliances and suggest that 
national trust has a direct governance implication for alliances. To the best of our knowledge, this is the first study to focus on the impact of national trust on alliance governance choices. This study thus answers the calls for further investigation of how national trust influences the organizational outcomes of international collaborations (Zaheer \& Zaheer, 2006).

Second, we begin to identify the conditions that moderate the effects of national trust in the context of governance choices in alliances. Social categorization theory predicts that the influence of social categories will weaken when familiarity with a (potential) partner increases. Applying this theoretical insight to alliance governance literature, we argue that the influence of national trust will weaken when information about the partner firm increases. We then suggest two situations that provide increased quality of information about the partner firm: (1) partnerspecific information through repeated alliances, (2) positions in an alliance network - firm centrality and membership of the same network community. Thus, we contribute to fuller and more complete understanding of when national trust matters more in the alliance governance decision.

\section{SHARED NATIONAL TRUST}

The social categorization literature suggests two conditions under which the categorization process is particularly robust: (1) when the distinction between in-group and outgroup membership is salient, and (2) when the situation is cognitively demanding (Macrae \& Bodenhausen, 2000). Both conditions are relevant to international alliance settings (Park \& Ungson, 2001). First, the competitive and divergent goals and inter-firm rivalry that often characterize international alliances encourage in-group/out-group biases (Gomes-Casseres, 1994). While groups may be categorized on multiple dimensions, easily accessible and highly salient social categories are most likely to be chosen to define a in-group/out-group memberships (Hsu 
\& Elsbach, 2013). In the context of cross-border alliances, a national membership is likely to be one of the most salient features as it is central, enduring, and distinctive (Zaheer \& Zaheer, 2006). Second, alliances in an international context are cognitively demanding because of technological uncertainty (Mohr \& Spekman, 1994), causal ambiguity (Shenkar \& Zeira, 1992), and cultural dissimilarity (Park \& Ungson, 1997). Thus, the categorization process is likely to apply to international business alliances. Since social categorization on the basis of country has been associated with national character categories (i.e., stereotypes) (Terracciano \& McCrae, 2007), categorization process may therefore trigger shared beliefs about the members of other countries, including the decision to trust or not (Ertug, Cuypers, Noorderhaven, \& Bensaou, 2013; Guiso, Sapienza, \& Zingales, 2009; Mackie, 2001; Muethel \& Bond, 2013).

In conceptualizing category-based trust in the context of international alliances, we are referring to manager's trust in partner managers and their firms based on the partner firm's country of origin. As such, national trust by the trustor manager is directed towards a trustee that may be an individual manager and/or a collective actor, such as an organization (Doney \& Cannon, 1997; Inkpen \& Currall, 1997; Janowicz \& Noorderhaven, 2006). Traditionally, trust between a trustor manager and a trustee manager has been referred to in prior work as 'interpersonal trust', while trust between a trustor manager and a trustee organization has been referred to as 'inter-organizational trust' (Zaheer, et al, 1998). Such a conceptualization of trust in which the individual manager acts as the trustor avoids the risk of 'anthropomorphizing' the organization as a trustor (Zaheer, McEvily, \& Perrone, 1998). In this section, we review the literature on how national trust operates at both the individual managerial level and the organizational level. 
In cross-border alliances, at the individual managerial level, we assume that a firm's manager's trust in partner managers is derived from shared cognitions held collectively by members within the trustors’ nation (Dyer \& Chu, 2000; Guiso, Sapienza, \& Zingales, 2006; Janowicz \& Noorderhaven, 2006; Markus \& Zajonc, 1985). Many field studies have shown that managers in a focal country share categorical beliefs about the trustworthiness of managers from other countries (e.g., Burns, Myers, \& Kakabadse, 1995; Ertug, Cuypers, Noorderhaven, \& Bensaou, 2013; Ferrin \& Gillespie, 2010; Mackie, 2001; Muethel \& Bond, 2013). In addition to these findings from field settings, similar results have also been shown in a laboratory setting. Individuals have been shown to share categorical assumptions (or stereotypes) with their fellow country persons about the trustworthiness of members from other nationalities. In one such study, doctoral students from different European nationalities shared similar perceptions of Southern Europeans as less trustworthy than Northern Europeans (Bornhorst, Ichino, Schlag, \& Winter, 2004). These convergent findings in both field and laboratory suggest that even educated individuals may apply shared cognitive shortcuts (e.g., Bazerman \& Moore, 2013) in which country-level categories provide proxy information about the trustworthiness of members from other nations. This conclusion is also consistent with a broader argument that organizational members are embedded in their national cultural environment (Brief, Butz, \& Deitch, 2005; Brief, Umphress, Dietz, Butz, Burrows, \& Scholten, 2005; Dietz, Robinson, Folger, Baron, \& Schulz, 2003) and that “... employees come to the organization with heavy cultural and social baggage obtained from interactions in other social contexts ...” (Scott, 2003: 23).

In addition to the individual managerial level, national trust may also be operating at the organizational level. Shared national cognitions of members within a focal country about members of other countries may be further reinforced in organizations. This occurs as managers 
in a focal country's firm interact with each other, sharing and reinforcing their mutual mental models conditioned by the shared norms and culture of the focal country (Pettigrew, 1979). Even in a multi-national firm in which some managers may not originate from the firm's country-oforigin and hence do not necessarily share the country-of-origin's cultural biases, these managers are still likely "enculturated" by the existing cultural biases held by the majority of members within the firm (Sussman, 2011).

Several studies have shown that stereotypical judgments held by individuals within a home country can "spill over" to influence categorization of individuals within a specific organization from a foreign country (Kostova \& Zaheer, 1999). For instance, MacDuffie (2010) has written about Japanese/Chinese relationships in the auto manufacturing industry. He argued: “... historical mistrust between Japan and China at the national level translate into identity-based attributions, on both sides, regarding the trustworthiness of Japanese automakers and Chinese suppliers ...” (MacDuffie, 2010: 42-43). In the marketing literature, the term, "country of origin” has been used in multiple studies to analyze how the home country impacts perception of multinational firms (Al-Sulaiti \& Baker, 1998). Although these studies have not examined national trust per se, they point to an underlying impression formation mechanism at the organizational level that is similar to national trust operating at the individual level.

\section{NATIONAL TRUST AND ALLIANCE GOVERNANCE}

National trust, a cognition held by organizational members, likely influences organizational outcomes. There is a sizeable literature on the influence of managerial cognition on organizational decisions (Carpenter, Pollock, \& Leary, 2003; Finkelstein, Hambrick, \& Cannella, 2009). As stated by Hambrick (1989: 5), “... biases, blinders, egos. . . and other human factors in the executive ranks greatly affect what happens to companies ...” Accordingly, when 
managers involved in cross-border alliance activities are influenced by national trust, the influence will likely spill over to the governance decision of the alliances with the other firm.

According to this inter-organizational governance literature (Hagedoorn, Cloodt, \& Kranenburg, 2005; Hennart, 1988; Kogut, 1988; Oxley, 1999; Powell, 1990), firms choose between several alternative governance modes in organizing their alliance activities. We focus here on two such alternatives: contract-based governance and equity-based governance. Contract-based governance is a contractual arrangement in which partners pool their capabilities but do not form a separate legal entity for the alliance. In contrast, firms can also pool capabilities under an equity joint venture, but in this case a new entity is created, jointly owned and operated by two or more collaborating firms (Oxley, 1997; Pisano, 1989). According to the market-hierarchy of organizational choices suggested by transaction cost economics (Williamson, 1975), equity joint ventures are akin to hierarchies because they create a separate administrative structure with formal control mechanisms. In contrast, contractual alliances are more loosely structured, based on incomplete contracts, while neither administrative control nor ownership control play a role in these contractual alliances.

The inter-organizational governance literature commonly posits that an organization chooses a governance mode according to its need to minimize opportunistic behavior by transaction partners. If concerns over opportunism are relatively low, contract-based governance is considered more efficient than equity-based governance (Oxley, 1999). However, if the risk of opportunism is high, equity-based governance is favored over contract-based governance. High risk of opportunism creates a 'mutual hostage' in which shared equity helps align the interests of both partners (Hennart, 1991) because the concern of both firms for their initial and ongoing equity investments reduces the incentive to behave opportunistically (Williamson, 1975). 
Trust between alliance partners can also be used to mitigate opportunism and allow organizations to take what Williamson (1975) calls 'calculative risks' because organizations expect that their counterparts will act in a less opportunistic manner. The benefits of trust in alliances have been described in prior work: “. . . trust avoids contracting costs, lowers the need for monitoring, and facilitates contractual adaptation. Trust counteracts fears of opportunistic behavior and as a result, is likely to limit the transaction costs associated with an exchange” (Gulati, 1995: p. 93). A lack of trust, on the other hand, requires more effort to control opportunism, which leads to higher transaction costs (Li, Boulding, \& Stael, 2010).

Thus, studies have found that the greater the trust between partners in an alliance, the more likely the alliance is to be contract-based. For example, Gulati (1995) found that firms with prior interactions are likely to rely on trust and contract to govern their cooperative relationships rather than costly equity joint ventures or large shares of equity ownership (see also Inkpen \& Currall, 2004). Additionally, the benefits of relying on trust were more significant when equitybased governance was absent (Zollo, Reuer, \& Singh, 2002).

Yet, the primary focus of these previous studies was on trust across organizational rather than national boundaries. In contrast, our focus is on how trust across national boundaries influences the choice of governance mode in international alliances. When a firm decides to pursue an alliance with a firm from another country, the impression about the partner firm's home country likely influences how much the partner firms will be trusted, which may ultimately impact the choice of alliance governance mode.

The association between national trust and inter-partner trust in an alliance has been well documented. For example, Zaheer and Zaheer (2006) elaborated on this theoretical association, which Ertug and colleagues (Ertug, Cuypers, Noorderhaven, \& Bensaou, 2013) demonstrated 
empirically in a sample of international joint ventures. Therefore, building on this research, we examine the governance outcomes of such trust and expect that if a firm has a high degree of national trust toward its partner firm, it will be less likely to anticipate opportunistic behavior from this partner and will use a less costly contract-based governance mode. On the other hand, if a firm has a low level of national trust toward its partner, it will be more likely to resort to equity-based governance to curb the transaction costs associated with potential opportunistic behavior from its partner firm.

Hypothesis 1: There will be a negative relationship between national trust and equity-based governance structures.

\section{MODERATING THE EFFECTS OF NATIONAL TRUST}

Although we posited a negative relationship between national trust and equity-based governance structures, the influence of national trust on alliance governance decisions should diminish as a firm gains specific trust-relevant information about a partnering firm. The trust literature notes that category-based trust is fragile because its "tentative and assumption-based nature”, and as such is vulnerable to change if it is contradicted by more specific, additional information (McKnight, Cummings, \& Chervany, 1998: p. 483). Consistent with this prior research on trust, the established literature on country of origin effects (Al-Sulaiti \& Baker, 1998) shows that the general effect of national stereotypes on initial product perception is mitigated when consumers gather specific information about foreign products. Along these lines, individuals with high levels of information on foreign products (i.e., experts) rely on stereotypes less frequently than individuals with more limited information (i.e., novices) (Maheswaran, 1994; Sujan, 1985). Similarly, the social cognition literature has shown that when trustors have limited information about trustees they are prone to using social group stereotypes; but as 
information on trustees increases, the influence of stereotypical judgment dissipates (Brewer, 1988; Fiske \& Neuberg, 1990; Wyer \& Carlston, 1979).

Consistent with this prior theory-driven work on trust, we propose that in the context of international alliances, the influence of stereotype-based national trust will be reduced when firms gain more information about their alliance partners. Specifically, we consider the role of two mechanisms that allow firms to gain additional information on (potential) partner firms, thereby mitigating the influence of national trust: (1) repeated alliances, (2) organizational reputations transmitted through alliance networks. While repeated alliances offer participating firms an opportunity to gather firsthand information about each other, organizational networks allow participating firms to learn about partner firm's reputations based on secondhand information. In the moderating hypotheses below, we posit that as information quality about the partner firm increases with direct experience and with network connections, the initial effects of national trust will diminish.

\section{Repeated alliances}

Both the contact hypothesis (Allport, 1954) and social categorization theories (for review, see Paluck \& Green, 2009) suggest that, if there is little contact between groups, trust will depend largely on the category membership associated with the group. However, as the frequency of personalized interaction and communication increases, the trustee's individual attributes become more visible to the trustor. Gradually the trustor comes to emphasize individual attributes of the trustee (learned from the interactional history) over category membership. Research has shown that individuals consider firsthand information obtained from direct contacts to be more reliable than indirectly observed information (i.e., category membership) (Fazio \& Zanna, 1981; Locksley, Borgida, Brekke, \& Hepburn, 1980; Nisbett, 
Zukier, \& Lemley, 1981). Thus, as the frequency of interaction between individuals increases, we anticipate a shift from trust based on category membership to trust based on partner attributes (for a similar argument, see Becerra \& Gupta, 2003).

In the context of alliances, as firms enter into repeated relationships with prior partners, each firm will likely develop a better understanding its partner's difficult-to-observe characteristics such as cultures, management systems, and capabilities (Zollo, Reuer, \& Singh, 2002). The mutual understanding that develops with experience provides partner-specific learning opportunities. Through this learning, organizational decision makers evaluate whether national trust toward their alliance partners is justified. If a category based cognition is judged as accurate, then trust judgment based on national membership will remain unchanged. However, category-based cognition is a relatively primitive form of trust. As such it is more likely to lapse or break down over time because this form of cognition is based on general information and often overlooks information that is specific to individuals (Meyerson, Weick, \& Kramer, 1996). When direct experience supplies partner-specific facts that displace an initial impression, organization decision makers will come to discount the stereotype-based initial impressions (McKnight, Cummings, \& Chervany, 1998) and revise their beliefs to reflect their direct observations about the partner firm.

Although recent research has shown that the effect of national trust on inter-partner trust weakens with prior alliances (Ertug, Cuypers, Noorderhaven, \& Bensaou, 2013), it still remains unclear whether prior alliance experiences also weaken the effect on national trust on governance choices. Building on this prior work that the influence of national trust on partner firm trust will decrease with the prior alliance experience, we argue that national trust's impact on alliance governance will decrease as well. Thus: 
Hypothesis 2. The influence of national trust on alliance governance will decrease as a firm has more prior alliance experiences with a partner firm.

\section{Organizational reputation transmitted through alliance network}

Drawing on signaling theory, Fombrun (1996: p. 37) defined organizational reputation as, "the overall estimation in which a company is held by its constituents." The literature on organizational reputation (Barnett \& Pollock, 2012) suggests that this overall estimation includes not only information about financial performance, but also such non-financial attributes as behaving opportunistically in relational contexts (McKnight, Cummings, \& Chervany, 1998).

Applying this concept of organizational reputation to the international alliance setting, we argue that a firm can learn about its partner firm's reputation to behave opportunistically through organizational networks. Research has documented the importance of social networks in transmitting reputation at both the interpersonal and the inter-organizational level. At the interpersonal level, the social network literature has shown that when two individuals are connected together through a third party, reputation information about the tendency to behave opportunistically may flow from the third party to each of the two individuals (Burt \& Knez, 1995; Ferrin, Dirks, \& Shah, 2006; Raub \& Weesie, 1990; Wong \& Boh, 2010). Thus, even though a focal individual may not have any firsthand interaction with another individual, secondhand information about that individual's opportunism may be provided through a social tie. Similarly, at the inter-organizational level, third parties can function as 'referrals' by conveying a firm's reputation for opportunism to new entrants who do not have a prior relationship with the firm (Uzzi, 1997). Thus, inter-organizational networks act like a broadcast system for the organization's tendency to behave opportunistically. Drawing on organizational network literature, we argue that (a) network centrality and (b) membership of the same network 
community as its potential partner firm will increase a focal firm’s information about its potential partner firm's opportunistic tendencies, and as such decrease its reliance on national trust.

Organizational network studies have shown the numerous benefits of network centrality for a firm. A central network position awards a firm with information acquisition and knowledge gains (e.g., Ahuja, 2000; Mowery, Oxley, \& Silverman, 1996; Schilling \& Phelps, 2007). It also provides access not only to the information held by that firm's partners but also to the information held by its partner’s partners (Gulati \& Gargiulo, 1999). Consequently, the more central a firm's position in a network, the more information sources it can potentially access (Brass, Galaskiewicz, Greve, \& Tsai, 2004; Gnyawali \& Madhavan, 2001; Gulati, 1998; Powell, Koput, \& Smith-Doer, 1996; Tsai \& Ghoshal, 1998).

Information transmitted within the network often includes a firm's reputation for opportunism. Because network centrality allows a firm to learn about the reputation of other firms more easily than firms less centrally located, a more centrally located firm will better assess which firms in the network have a reputation for behaving opportunistically. As a firm weighs the validity of stereotype-based national trust associated with a partner firm against its organizational reputation for opportunism, it will likely put more weight on the partner's organizational reputation information because this information is individual-specific rather than group-based and general. Thus, we posit that as centrally located firms gain more information about partnering firms’ reputation for opportunism through their alliance networks, the less reliant they become on such general impressions as national trust.

In addition to network centrality, membership of a network community may also influence the diffusion of information about a firm's reputation to behave opportunistically. Because a firm interacts more with other firms in similar product markets or in close geographic 
proximity (Rosenkopf \& Almeida, 2003), its organizational networks are often highly segmented. Clustered firms in a segmented network have more ties to each other than more distal firms in the network (Schilling \& Phelps, 2007) and thereby form a network community. Information within such network communities or subgroups may travel faster and more efficiently than information from outside these communities (Greve, 2009; Schilling \& Phelps, 2007; Sytch \& Tatarynowicz, 2014; Sytch, Tatarynowicz, \& Gulati, 2012). Thus, dense network communities give rise to richer and greater amounts of information exchange, which subsequently contributes to the development of trust and social capital (Adler \& Kwon, 2002; Coleman, 1992; Kwon, Heflin, \& Ruef, 2013; Putnam, 1993). Accordingly, since the network can be also conceived as a collection of multiple subgroups of individual firms, members of the network community may assess other member firm's reputation to behave opportunistically more efficiently than the reputation of non-member firms (Sytch \& Tatarynowicz, 2014).

Based on this network logic, firms entering international alliances within the same network community benefit from rich information transmission that provide safe-guards against possible opportunistic behavior (Uzzi, 1997). Hence, superior information transmission within the same network community likely weakens a firm's reliance on national trust as it provides more detailed information on partner firms than category-based national trust. By contrast, when firms from different network communities enter an alliance, information transmission across the two network communities is less likely to be as rigorous as information transmission within a particular network community. Consequently, when alliance partners are from different network communities, both alliance partners are more likely to rely on category-based trust in assessing the trustworthiness of their partnering firms. 
To summarize, we expect that the influence of national trust on alliance governance will decrease as a firm gains more partner-specific information either from its centrality position in the network or from its membership within the same network community in the alliance network. Since forming and maintaining network ties are costly, network scholars have noted a potential trade-off between creating links to a wide range of firms through network centrality versus forming densely linked network communities (e.g., Burt, 2000). Accordingly, we generate two complementary moderation hypotheses in which the network characteristics of centrality and membership in network community increase information transmission and thereby decrease the influence of national trust:

Hypothesis $3 a$. The influence of national trust on alliance governance will decrease as a firm increases its centrality in the international alliance network.

Hypothesis $3 b$. The influence of national trust on alliance governance will decrease as a firm creates an alliance with a firm from the same network community in the international alliance network.

Data and Sample

\section{METHODS}

The alliance data for this study are from the MERIT-CATI databank (see Hagedoorn, 2002, for an overview of the dataset). For our current analysis, we use data on research and development (R\&D) alliances while we exclude other types of alliances such as production and marketing alliances, because $\mathrm{R} \& \mathrm{D}$ alliances are not only the largest group of alliances within the database, but are also the most homogeneous category (Hagedoorn, 2002).

Our choice of the MERIT-CATI databank has several important advantages. First, because of the high potential for leakage of valuable intellectual property (i.e., the appropriability hazard), trust matters more in R\&D alliances than other forms of partnerships such as standard customer-supplier relationships, second sourcing, or joint marketing agreements (Levin, 
Klevorick, Nelson, \& Winter, 1987; Teece, 1986). The MERIT-CATI databank specifically focuses on the comprehensive coverage on R\&D alliances (Hagedoorn, 2002). Second, to rule out a possibility that the findings reported here may be idiosyncratic to particular technology fields, the data include a broad spectrum of technology fields. These fifteen fields range from high-technology fields such as pharmaceutical biotechnology to less technology-intensive fields such as food and beverages. Finally, unlike other large alliance databases (e.g., SDC, CORE, RECAP, and BIOSCAN), the MERIT-CATI database is the only source that allows us to look at long-range historical trends beginning as early as 1960 (Schilling, 2009), which is crucial to understanding the influence of early alliances. While SDC, the other major alliance dataset, covers a wide range of alliances types, including sales and marketing alliances and manufacturing agreements, the SDC dataset is sparsely populated until 1990 (Anand \& Khanna, 2000).

Because the risk of malfeasance increases substantially when the exchange is more complex (as in international commerce, where differences in law, physical distance, and language add to complexity), we focus on a relatively homogeneous set of countries, namely Western European countries that joined the European Union, thereby ruling out other explanations for the role of national trust. Overall, we analyzed 755 international R\&D alliances announced between 1970 and 2000, ${ }^{2}$ which are sponsored by 598 firms from 12 European countries. We focused on these countries because of the available information on bilateral (twoway) national trust.

\section{Dependent Variable}

The dependent variable is the choice of governance structure for each $R \& D$ alliance and is coded 1 if the alliance is organized as an equity joint venture and 0 if the alliance is organized 
as a contractual alliance. While a finer breakdown of the governance structure is possible in principle, we decided to use the dichotomous distinction between equity and non-equity governance for two reasons: (1) this dichotomous distinction agrees with the previous measure of alliance governance types in the literature (Hagedoorn, 2002); (2) it is empirically difficult to further distinguish among non-equity governance because more detailed types often overlap with each other. ${ }^{3}$

Independent Variables

National trust. Data on national trust in European countries are available from Eurobarometer surveys (see Mackie, 2001, for more info). The survey is designed to measure attitudes toward the Common Market and European Union institutions. Several thousand people from each country responded to the survey. The interviewer asked citizens of a given country the following question: "I would like to ask you a question about how much trust you have in people from various countries. Please tell me whether you have a lot of trust, some trust, not very much trust, or no trust at all.” Respondents are asked to rate their own country and other European countries. We coded the answers to the trust question as 1 (no trust at all), 2 (not very much trust), 3 (some trust), and 4 (a lot of trust). The responses were aggregated by country. Because the national trust question was available in the 1970, 1976, 1980, 1986, 1990, 1993, 1994, and 1996 surveys, we assigned the most recently available national trust score to a firm (e.g., we assigned the 1996 trust score to participating firms in alliances that ranged in time from 1996 to 2000).

Because each participating firm in an alliance yields its own national trust score, we classified each firm in terms of relative strength of national trust. For example, firm A might have a national trust score of 4 toward partner firm B, and firm B might have a national trust 
score of 3 for partner firm A. Accordingly, we label firm A as having higher national trust than firm B.

In the context of international alliances, Ertug, Cuypers, Noorderhaven, \& Besaou (2013) made a strong case that the construct of the propensity to trust is distinct from the construct of national trust toward other countries. In order to rule out the possibility that our national trust effect is not a mere proxy for the propensity to trust (i.e., the trustfulness of the trustor), we calculated how much people from a given country, on average, trust foreigners, and subtracted it from the country’s national trust score. This approach has been commonly used in the network literature (e.g., Gargiulo, Ertug, \& Galunic, 2009) and offers a more precise measure of national trust.

Despite the simplicity of our trust measure, there is considerable evidence of its psychometric adequacy. Cross-national studies have demonstrated that the trust scores extracted from the Eurobarometer surveys are extraordinarily stable across time and across countries (Mackie, 2001). Furthermore, Guiso, Sapienza, \& Zingales (2009) conducted a separate survey measuring the trustworthy of a generic citizen in different countries and found their measure highly correlated with the measure of trust used in the Eurobarometer survey. This correlation suggests we are measuring a common social reality rather than a methodological artifact.

Alliance experiences with the same partner. We counted the number of prior alliances between the firms in an alliance. ${ }^{4}$ This variable was coded 0 for a first-time alliance. Consistent with the prior literature (Kogut, 1988), we use the five year moving window which counted only the number of alliances formed in the previous 5 years. ${ }^{5}$

Centrality in alliance network. To compute the network centrality measure, we constructed adjacency matrices representing the relationships between the organizations for each 
year based on an alliance. For each matrix, we included all international alliance activities among organizations formed in the previous 5 years, thereby updating alliance information for each year. All matrices were input into UCINET (Borgatti, Everett, \& Freeman, 2002) to create a centrality score for each firm. The larger the centrality score, the more the firm occupied a central role in the alliance network. For the measure of centrality, we used closeness, capturing how closely connected a firm is to the rest of the organizations in the inter-firm network, both directly and indirectly (Freeman, 1979). Organizations with a high closeness centrality score are likely to have easier, quicker access to all the firms in the alliance network and thus have more information about all the possible partners in the network than organizations with a low centrality score. ${ }^{6}$ We included centrality measures from each participating firm in an alliance separately, which resulted in two centrality scores per alliance.

Membership in network community. To identify network communities, we used the algorithm developed by Girvan and Newman (2002) and implemented in UCINET. Using the same adjacency matrices as the ones used for the centrality measure, the algorithm assesses the quality of each community partition in a numerical score called 'modularity.' Values above 0.3 typically indicate a strong degree of community that could not be obtained by chance (Newman, 2003). Once the communities are identified, the value of membership in the same network community is coded 1 if a firm in an alliance is from the same network community as its partner firm, and 0 otherwise.

Control Variables

Distinguishing the effect of national trust from other explanations is a challenge, given its inherently subjective nature. In order to show that national trust influences alliance governance choice independent of other notable factors, we included a variety of control factors known or 
expected to affect the governance choices of alliances but not included in the discussion of the hypotheses. These include measures at the international level as well as inter-firm level. When relevant, control variables are entered separately for each participating firm in an alliance.

Variance of national trust. Because our national trust measure is derived from the mean value of responses in each country, the measure might disguise the heterogeneity of trust perceptions about a partner firm's country (see Au, 1999, for a similar criticism on Hofstede's cultural dimensions). To address this concern, we measured the variance of national trust from a particular firm's country. Thus, a lack of national consensus about the trustworthiness of a partner country will be reflected in a wide variance of the national trust measure.

Alliance experiences with partner firm's home country. We constructed a measure that uses each firm's number of prior alliances with firms headquartered in the current partner firm's country. We counted all the prior alliances each firm has entered during the prior five years with any partner from the same country as the current partner firm.

Economic distance. In order to capture multiple, distinct characteristics in which national economies differ, we relied on a cross-national economic distance measure, developed by Berry and her colleagues (2010). In creating the economic distance measure, they used the income level (GDP per capita) of a country, prevailing inflation rates, and intensity of trade with the rest of the world (exports plus imports as a proportion of GDP).

Technological factors. While there have been many measures comparing technological capabilities of nations (Archibugi \& Coco, 2005), we used the total R\&D expenditure at the national level and the number of firms in the same fields of technology in the country. Information on the total R\&D expenditure was accessed through European Commission's Eurostat website (http://epp.eurostat.ec.europa.eu/portal/page/portal/eurostat/home). The 
availability of partner organizations in a partner country that share a similar technology might also influence the choice of the governance. Therefore, we control for the number of prospective partner firms (firms that draw on the same fields of technology) within the home country of a partner firm. Finally, we used the number of patents filed by each firm in an alliance during the last five years (data came from European Patent Office website) to control for the technological heterogeneity of firms in an alliance.

Geographical factors. We included geographic distance and common border variables. The geographical distance between two countries is the log of distance in kilometers between the capital cities of the respective countries. We also added a dummy variable to indicate when two countries share a common land border. The dataset was available from Jon Haveman's International Trade Data website (http://www.macalester.edu/research/economics/page/haveman/trade.resources/tradedata.html). Institutional factors. We included International Intellectual Property Regime (IPR) score and legal origin to control for national institutional factors. To measure the difference in intellectual property rights protection in the home countries of partner firms, we used the information found in Ginarte and Park (1997) and additional data provided by Walter Park. Their data provided an index of patent rights protection with 5-year intervals (the years 1975, 1980, 1985, 1990, and 1995) for a large number of countries. We assigned each R\&D alliance and the countries of the sponsoring firms to the first year of the interval given for these patent rights protection indexes. For instance, all alliances found in the year 1977 refer to the patent rights protection indexes for the earlier year 1975. In the statistical analysis, we used patent rights protection indexes to measure the difference in the intellectual property rights protection within the home countries for both participating organizations. Commonality in legal origin may 
influence organizations to adopt contractual forms because it is easier for them to obtain legal justice in case of deviation from the legal contract. We used the Djankov, Porta, López-deSilanes, \& Shleifer (2003) classification of legal origin (e.g., English common law, the French commercial code, the German commercial code, Scandinavian civil law, and Socialist civil law) and constructed a dummy variable equal to 1 when the legal systems of two countries had a common origin, and 0 otherwise.

Cultural factors. We included three standard culture variables from the international business literature to characterize differences between the countries from which firms in an international R\&D alliance originate. For cultural distance we used the well-known Kogut and Singh (1988) index of cultural differences between countries, based on Hofstede (1980). Additionally, we measured religious similarity, the empirical probability that two randomly chosen individuals in two countries will share the same religion, by using an indicator of religious similarity developed by Guiso, Sapienza, \& Zingales (2009). We took the product of the fraction of individuals in country A and in country B who have religion C, and then summed across all religions C ( $\mathrm{C}=$ Catholic, Protestant, Jewish, Muslim, Hindu, Buddhist, Orthodox, no religion, other affiliation). Finally, we used the common language variable to indicate whether partner countries share the same language.

Percentage of equity alliances. We also included a control variable assessing the percentage of equity alliances in the same field of technology by counting the number of alliances announced in the same technology field during the last five years and computing the percentage of those that were equity based. In a limited way, this variable tests the institutionalist claim that organizations mimic the prevalent alliance governance forms of other organizations in their field of technology use (Gulati, 1995). This variable can also be interpreted as capturing the 
net effect of the various macroeconomic factors within a technology field that may influence the formation of equity alliances (Amburgey \& Miner, 1992).

Analysis

This study uses a data set that contains information about two levels of social entities (firms and countries) because individual firms are embedded in countries. Therefore, the hypotheses were tested using multilevel logistic regression technique called hierarchical generalized linear modeling (HGLM) (Guo \& Zhao, 2000; Raudenbush \& Bryk, 2002). Because some firms enter alliances multiple times, the large number of repeat occurrences of some firms can lead to systematic underestimation of the standard errors for firm attributes that do not change from alliance to alliance. The HGLM approach we used in this paper handles this issue by providing robust estimation of standard errors, which gives somewhat less weight to the extreme cases or outliers when the sample size of alliances per country-dyad varies. To control for the heterogeneity in the period, country, and technology effects, we also used a fixed-effect model. To assess support for the moderation hypotheses, all variables were grand mean centered prior to calculating the interactions, as recommended by Aiken and West (1991) and Jaccard, Turrisi, \& Wan (1990).

\section{RESULTS}

Table 1 summarizes correlations for all variables used in the analyses. To test for the possibility of multicollinearity among the variables, we calculated variance inflation factors (VIFs) using a fully specified model with all the variables. VIFs for our key independent variables, the national trust measures of the higher and lower national trust partners, were 7.65 and 6.56 respectively, which is below a conventional benchmark of 10 for the evidence of multicollinearity (Neter, Wasserman, \& Kutner, 1990). However, there is an interesting debate as 
to what constitutes the most appropriate bar for evidence of multicollinearity. In contrast to the conventional benchmark, many statisticians recommend a closer examination for multicollinearity under conditions in which the VIF score exceeds 2.5 (Allison, 1999) or 5 (Huber \& Stephens, 1993; Menard, 1995). One test to further determine multi-collinearity effects is the condition number, which uses the eigenvalues of the model matrix. Belsley, Kuh, and Welsch (1980) suggest an information rule that a condition number over 30 suggests multi-collinearity. We found a condition number of 3508, which is well above the informal rule, which suggests multicollinearity between our national trust variables. Moreover, the national trust measures of the higher and lower national trust partners were highly correlated (alpha=0.73). Since high VIF scores, a high condition number score, and high correlations are all warning signs of multicollinearity, to ensure the validity of our results, and the stability of our models, we orthogonalized the national trust variables using a modified Gram-Schmidt procedure (Golub \& Van Loan, 1996). This procedure removes common variance to ensure that two formerly multicollinear measures act independently and therefore increase their discriminant validity.

[Insert Table 1 about here]

Table 2 shows national trust between countries of origin and those of target averaged across all surveys between 1970 and 1996, and shows three relevant findings. First, we find variation in how much a given country trusts and how much that country is trusted by others (see the last row and last column of Table 2). Our results show that from the perspective of individuals from other European countries, Danes are the most trusted while Italians are the least trusted. Moreover, we found that Italians trust the least while Swedes trust the most, which suggests that each country has an inherent propensity to trust. Second, even though national trust between country pairs is positively correlated in general, there are a few cases in which national 
trust was not always equally reciprocated. For example, the Dutch trust the Belgians (3.18) more than the Belgians trust the Dutch (2.9). This finding suggests we should investigate national trust at the country-level rather than at the country-dyad level as the latter masks the few asymmetric cases in national trust. ${ }^{7}$ Finally, the diagonal cells represent trust in own country persons. Though it is generally higher than national trust in people from other countries, some countries (e.g., Denmark, Netherlands, and Italy) deviate from this general pattern.

[Insert Table 2 about here]

Hypothesis 1 predicts that national trust will be inversely associated with equity based governance structures. Table 3 assesses the validity of Hypothesis 1 with the results from various model specifications. ${ }^{8}$ Given that our predictions are directional in nature, all reported analyses were conducted using one-tailed significance tests. In Model 1, we entered the national trust measure of the lower national trust partner. Controlling for inter-firm factors, Model 1 reveals a statistically significant negative coefficient $(\mathrm{p}<0.05)$ for this measure, which supports Hypothesis 1 . To interpret the meaningfulness of this significant coefficient, we found that a one standard deviation difference in national trust (0.26) was associated with a difference in the logodds of equity governance of $0.26 *(-0.77)=-0.2$ or a relative odds of $0.82(=\exp [-0.2])$. Holding all other variables at a fixed value, this finding demonstrates that a one standard deviation increase in national trust decreases the odds of equity-based governance by 18\% (i.e., =1-0.82). We then entered the national trust measures of the higher and lower national trust partners together in Model 2. Not surprisingly, we found the result similar to Model 1, again supporting H1.

[Insert Table 3 about here] 
Both Models 1 and 2 included numerous control variables at the country level, and confirm the significant effect of national trust on governance choice. However, even though our control variables at the country level are extensive, there might be unobserved variables not completely captured by our control variables. To address this issue, in Model 3, we ran country fixed effects by including dummies for both countries that each firm in the alliance comes from, and still found similar results. Moreover, to address a possible concern about the heterogeneity of alliance types, in Model 4 we excluded 'unilateral' contract-based alliances, such as licensing agreements, which involve little interaction between the parties and require little or no trust (Mowery, Oxley, \& Silverman, 1996). After using such a sample of bilateral contract-based alliances, we still found similar results.

Because Models 1-4 assume that firms are randomly assigned into alliances, we examined this assumption by estimating a two-stage Heckman Probit selection model in Model 5. Such an assumption may be problematic if selection into alliances hinges on a systematic sorting process. Because firms choose whether to enter into alliances, firms that do not trust their partner firm's country may be less likely to enter alliances with this firm, thereby biasing the sample of observed governance choices. To explore a possible bias, we ran a Heckman Probit selection model, using STATA's heckprob command and adjusted the standard errors by clustering cases at the country level. This Heckman Probit selection model was used because one binary dependent variable (e.g., equity governance choice) depends on another dependent variable (e.g., entering into an alliance). In the first step of this analysis, the dependent variable was the formation of a new alliance between two organizations in a given observation year. We listed all possible alliances $(n=57,727)$ from a set that included all firms that had entered at least one alliance in a given year within each field of technology. In that way, we captured the most 
relevant set of firms looking for alliance partners. We then coded a dichotomous dependent variable that indicated whether a firm entered an alliance in the given year with a partner firm.

The second step of the Heckman Probit selection model estimated the probability of equity governance choice, correcting for selection. Since the Heckman Probit model needs some exclusion restrictions that strongly affect the chances for observation (i.e., alliance formation) but not the outcome under study (i.e., governance choice), we used the fields of technology dummies for the first stage analysis, but omitted them for the second stage. ${ }^{9}$ The results of the first-stage selection model suggest that national trust, regardless of how it is measured, has no statistically significant impact on alliance formation. More importantly, the effect of both measures of national trust on governance decisions remains significant even after accounting for selection issues. This is further supported by the reported Wald $\chi^{2}$ test of the selection model, which was not statistically significant, suggesting that selection bias did not affect our HGLM results. $^{10}$

Hypotheses 2, 3a, and 3b predicted that the influence of both national trust scores (i.e., higher and lower) on alliance governance will decrease as information about a partner firm increases. To test these three moderation hypotheses, we introduced the cross-level interactions of national trust with variables at the firm level in Models 6 to 9 of Table 4. Because there are two national trust scores from each alliance (i.e., lower and higher scores from each participating firm), we included two interaction terms for each model.

[Insert Table 4 about here]

Hypothesis 2 predicted that the influence of national trust on alliance governance will decrease as a firm has more prior alliance experiences with a partner firm. Model 6 reveals a strong support. The interaction terms are statistically significant whether the lower/higher 
national trust partner is used, which supports Hypothesis 2. Using the results from the full interaction model (Model 9), the combined effects for lower national trust and repeated equity alliances with the firm are as follows:

$P=1 /\left(1+e^{-[-0.21 * \text { lower national trust-0.07 *alliance experiences with the same partner }+0.08 * \text { lower national trust* alliance }}\right.$ experiences with the same partner] )

The effect of repeated alliances under conditions in which the national trust measure of the lower national trust partner is used is plotted in Panel A in Figure 1. High and low levels of national trust are set at \pm 2 standard deviations from the mean. Panel A in Figure 1 shows that the national trust of the lower national partner decreases the probability of equity governance choice for alliances with no prior alliance experience, but for alliances with multiple repeated alliances, the probability of equity governance choices does not significantly change. When the national trust measure of the higher national trust partner is used instead in the interaction term, we again find a similar result (as graphed in Panel B in Figure 1). So, consistent with our hypothesis, national trust is most likely to influence firms with fewer repeated alliances.

[Insert Figure 1 about here]

Hypothesis 3a predicted that the influence of national trust on alliance governance will decrease as a firm has higher centrality in international alliance networks. Model 7 tests this hypothesis but the interaction term between national trust and centrality is not significant regardless of whether the higher or the lower national trust scores in an alliance dyad are used. Hence, no support is found for Hypothesis 3a. Hypothesis 3b predicted that the influence of national trust on alliance governance will decrease under conditions in which a firm has an alliance with a firm from the same network community in the international alliance network. Model 8 tests this hypothesis. The interaction term between lower national trust and membership 
in network community as well as the interaction term between higher national trust and membership in network community are significant. Hence, these results provide a support for Hypothesis 3b (see also Panel A \& B in Figure 2). Finally, in Model 9 we entered all interaction variables simultaneously in one model, and found the same pattern of results as with the individual interaction terms.

Robustness Checks

Country-specific experience. In addition to gaining information about a partner directly from past interactions or indirectly through an alliance network, it is also possible to gain information about the partner's country indirectly by learning from prior partners who came from the same country (Brewer \& Miller, 1984; Higgins \& King, 1981). Thus we examined whether, the more extensive a firm's alliance experience with any firms from a country, the less the influence of national (category-based) trust on alliance governance decisions. However, we did not find support for this idea (in the results unreported here). We suspect that a firm's gains from country-specific partner experiences are limited because some experiences are not completely fungible across alliances and entail relation-specific factors that emerge only in repeated alliances with specific partners or mediation through network contacts.

Alternative dataset. In our analysis, we utilized the MERIT-CATI database. However, while the coverage of alliance data in the MERIT-CATI is highly accurate and comprehensive, the MERIT-CATI database includes only strategic technology agreements and excludes a very wide range of other alliance types. Thus, data on all prior alliance experiences might be incomplete, raising questions about the validity of testing the moderation hypotheses. We replicated the reported results using the Thomson Reuters SDC Platinum database and found 
similar results at the same levels of significance. Thus, we are confident that our results are not a function of our choice of dataset.

\section{DISCUSSION}

We examined the influence of national trust on the choice of governance mode in alliances. Previous research and theory on inter-organizational trust often portrays a historybased view of trust development in which trust develops in response to prior interactions with the partner firm. In contrast, drawing upon insights from categorization-based social cognition literature, we developed general arguments about national trust in shaping the governance mode of international alliances and found support for our arguments. Our results demonstrate that trust may be established through category-based cognition (even without prior direct interactions). Additionally, we found partial support for the idea that the effect of national trust on alliance governance decreases as information about a partner firm increases. Specifically, we found moderating effects when a firm: (1) directly gains knowledge about a partner firm through repeated interactions or (2) indirectly gains knowledge about a partner firm by being a member of the same network community.

\section{Implications}

Our study contributes to a better theoretical understanding of how category-based national trust impacts alliance governance decisions. Even though repeated alliances and membership in network community lessened the influence of national trust, we found that the effect of national trust did not disappear. This finding is consistent with the previous micro-level research on category-based trust. This work suggests that the influence of category-based trust persists even when individuals are exposed to information about (a) the heterogeneity of members belonging to the category or (b) group members whose behavior is inconsistent with a 
formed stereotype (e.g., McKnight, Cummings, \& Chervany, 1998; Williams, 2001). Hence, when people experience opportunistic behavior of someone from an otherwise stereotypically trustworthy group, they often discount the individual as unrepresentative of the group or filter it out completely. When such trust violations are perceived as an isolated event, they often do not influence the overall perceptions of trustworthiness (Sitkin \& Bies, 1993). Consistent with this notion, prior work in psychology shows that once an impression is formed, evidence contrary to it is seldom sought and often ignored (Fiske \& Taylor, 1984; Tajfel, 1969). This result suggests that the effect of national trust may not completely disappear even in the presence of more disconfirming information from partner firms.

Our findings have practical implications which indicate that managers should be vigilant about relying too heavily on category-based information, and should be encouraged to critically examine such an assumption brought to governance decisions. In the construction of our national trust measure, our study controlled for the propensity of the focal country to trust (Ertug, Cuypers, Noorderhaven, \& Bensaou, 2013). But, even after the adjustment, we still found an impact for national trust, thereby further highlighting its unique role in governance decisions. In addition, this study highlights that encouraging trust at the organizational level alone might not be enough to manage inter-organizational trust, because of the additional influence of national trust derived from the country of origin. If managers involved in international alliances are made aware of these concerns, they may be motivated to pay more attention to national trust directed at the country of origin.

Our study also extends the inter-organizational relationship literature by introducing multi-level analysis. Because individual organizations are embedded in inter-organizational networks, and inter-organizational networks in turn are embedded in national environments 
(Hagedoorn, 2006), the international alliance context is particularly well suited for analyses at multiple levels. Few, if any, studies, however, have attempted to look at how an interorganizational network itself is also embedded in a broad national cultural context. By highlighting the source of inter-organizational trust from the broader context of national trust, we attempt to bridge across multiple levels.

In addition, we contributed to the traditional IB literature, which typically assumes that cultural distance is a general proxy indicator for national (dis)trust, but without critically testing this assumption. In contrast, our study shows that cultural distance has a low-order inverse correlation with national trust (see table 1), and that national trust influences alliance governance decisions above and beyond the influence of cultural distance, which suggests that national trust and cultural distance are distinct phenomena. Thus, we add value to the IB literature by directly distinguishing national trust from cultural distance and then determining its influence on alliance governance.

Finally, our study suggests that the effect of national trust on governance choices is partially mitigated if a firm (a) has prior alliance experience with its partner firm or (b) originates from the same network community as the partner firm. Our results are consistent with social categorization theory that predicts that the influence of social categories declines when familiarity with the target increases; we found that national trust becomes fragile with additional information on partner firms. While prior ties provide firsthand information about the partner firm, membership in network community provides secondhand information through networks. This suggests that, while the influence of national trust is persistent (as we discussed above), it is not immutable.

\section{Limitations and Future Research Directions}


The results and contributions of this study should also be considered in light of its limitations. First, the archival data used in this study cannot provide direct evidence that organizations rely on the international trust based on category membership in making the governance mode choices because our data do not allow us to directly observe category-based trust among personnel involved in the sample alliances. As such, future research might benefit from large-scale survey research that further explores the notion of international trust based on category membership in an international setting by investigating the attitude and decisionmaking process of alliance managers and other key personnel involved in alliances.

Second, our measure of national trust is rather crude given that trust is a complex construct, composed of multiple sub-dimensions. It is unlikely our measure captures different nuances associated with the construct, let alone variations across different societal contexts. Therefore, future research should include a more "emic" approach (Morris, Leung, Ames, \& Lickel, 1999) that considers differences in national and cultural contexts. On a related issue, our trust measures ask about how much survey respondents trust people in another country and not how much they trust firms from another country. We justified the use on the basis of data availability and on theoretical reasoning that a general view that citizens of one country hold about members of another country is indicative of the social context in which a firm is embedded. However, future studies should seek to more precisely assess national trust in a business context. Finally, our study does not include firm-level financial variables in the model because such historical firm data are not available for most of the European firms in our sample. However, prior literature shows that neither firm size nor firm sales is significant in firms' alliance governance mode decisions (Colombo, 2003; Li, Boulding, \& Stael, 2010; White, 2000). 
Thus, we are confident that the lack of firm-level financial data did not substantially influence the study's results.

\section{Conclusion}

This study aimed to underscore the need to move beyond the conventional sources of inter-organizational trust based on prior dyadic interactions in order to understand the conditions under which a broad social and cultural context matter. We suggest that researchers (and managers) need to take into account national trust toward the home country of partner firms in an alliance because it influences the governance mode adopted in the alliance. We hope that our study triggers future work beyond the inter-organizational level in order to develop a more complete picture of how broader national and cultural factors affect inter-organizational alliance governance. 
${ }^{1}$ This 'history-based' view (Kramer, 1999) of inter-firm trust has alternatively been called trust based on 'relation' (Ring \& Van de Ven, 1992), ‘process’ (Parkhe, 1998; Zucker, 1986), ‘knowledge/experience’ (Shapiro, Sheppard, \& Cheraskin, 1992), or 'shadow of the past' (Poppo, Zhou, \& Ryu, 2008).

${ }^{2}$ Since many firms existed prior to the sampling period, to address left-censoring concern, we ran the analyses including additional alliance data dating back to 1921 . The results were not substantively different due to small number of alliance activities before 1970 .

${ }^{3}$ For example, minority equity positions have at times been added to joint ventures to define the 'equity' category, or have been treated as a third typology of alliance governance. We performed additional analyses according to which equity alliances exclude minority stakes and found results substantially unchanged. Also, because minority investments play some role in biotech only (Hagedoorn, 2002), we include biotech as one of the fields of technology controls.

${ }^{4}$ We also explored an alternative variable, based on a count of all prior alliance experiences (as applied by Ertug, Cuypers, Noorderhaven, \& Bensaou (2013)) and found similar results.

${ }^{5}$ We also checked the results against networks that included all previous alliances and found no significant differences in the results. Redefining of this measure using the natural log transformation, to avoid possible skewness of the distribution, also yielded substantively similar results.

${ }^{6}$ Though we believe that the closeness centrality is theoretically the most appropriate measure for our purpose, we nevertheless tested the robustness of the findings with two additional measures of centrality--Bonacich's eigenvector centrality and also betweenness centrality. We also tried Burt's frequency decay measure that accounts for the decline in tie strength across progressively distant ties (Burt, 1992). We found no substantive differences in these additional analyses.

${ }^{7}$ We want to thank a reviewer for pointing this out.

${ }^{8}$ Although not the main focus of our analysis, Table 3 shows that the probability of equity governance decreases as the number of repeated alliances increases, consistent with the previous findings that familiarity breeds trust (Gulati, 1995).

${ }^{9}$ The majority, but not all, of the fields of technology dummies were significantly associated with the probability of selection, but not with governance choice. To ensure the validity of our results, we ran multiple models with sets of exclusion restrictions that were significantly related. Our results were robust across these different models. 
${ }^{10}$ Because the Heckman probit selection model is not a two-step procedure like the one used in the Heckman selection model, an inverse Mills' ratio is not involved in this estimation. 
TABLE 1. CORRELATION MATRIX

\begin{tabular}{|c|c|c|c|c|c|c|c|c|c|c|c|c|c|c|}
\hline & 1 & 2 & 3 & 4 & 5 & 6 & 7 & 8 & 9 & 10 & 11 & 12 & 13 & 14 \\
\hline 1. Equity-based alliance & 1 & & & & & & & & & & & & & \\
\hline 2. National trust $\mathrm{t}^{\mathrm{a}}$ & -0.14 & 1 & & & & & & & & & & & & \\
\hline 3. National trust ${ }^{\mathrm{b}}$ & -0.13 & 0.73 & 1 & & & & & & & & & & & \\
\hline 4. Alliance experiences with the same partner & -0.04 & 0.02 & 0.07 & 1 & & & & & & & & & & \\
\hline 5. Alliance experiences with partner firm's home country ${ }^{\mathrm{a}}$ & 0.01 & 0.05 & 0.06 & 0.56 & 1 & & & & & & & & & \\
\hline 6. Alliance experiences with partner firm's home country ${ }^{\mathrm{b}}$ & -0.03 & 0.03 & 0.07 & 0.68 & 0.47 & 1 & & & & & & & & \\
\hline 7. Centrality ${ }^{\mathrm{a}}$ & 0.03 & 0.1 & 0.02 & 0.19 & 0.32 & 0.16 & 1 & & & & & & & \\
\hline 8. Centrality ${ }^{\mathrm{a}}$ & 0.02 & -0.04 & 0.01 & 0.27 & 0.26 & 0.36 & 0.33 & 1 & & & & & & \\
\hline 9. Membership in network community & -0.03 & -0.03 & -0.03 & -0.06 & 0.1 & 0.04 & 0.21 & 0.28 & 1 & & & & & \\
\hline 10. Variance of national trust $\mathrm{t}^{\mathrm{a}}$ & 0.1 & -0.58 & -0.59 & -0.02 & 0.08 & 0.05 & 0.01 & 0.08 & 0.09 & 1 & & & & \\
\hline 11. Variance of national trust ${ }^{\mathrm{b}}$ & 0.05 & -0.5 & -0.57 & 0 & 0.05 & 0.05 & -0.01 & 0.04 & 0.03 & 0.69 & 1 & & & \\
\hline 12. Economic distance & 0.05 & -0.26 & -0.31 & 0.04 & -0.01 & 0.01 & -0.08 & -0.12 & -0.07 & -0.25 & -0.28 & 1 & & \\
\hline 13. R\&D expenditure ${ }^{\mathrm{a}}$ & -0.03 & 0.21 & 0.32 & 0.11 & 0.12 & 0.12 & 0.04 & -0.02 & 0.04 & -0.3 & -0.18 & 0.23 & 1 & \\
\hline 14. $R \& D$ expenditure ${ }^{b}$ & -0.06 & 0.22 & 0.19 & 0.09 & 0.08 & 0.1 & 0 & 0.06 & -0.04 & -0.25 & -0.11 & 0.09 & -0.21 & 1 \\
\hline 15. \# of firms within the same field of technology ${ }^{a}$ & -0.24 & 0.08 & 0.19 & 0.04 & -0.01 & 0.06 & -0.1 & -0.09 & -0.07 & 0.08 & 0.04 & 0.07 & -0.05 & 0.06 \\
\hline 16. \# of firms within the same field of technology & -0.25 & 0.21 & 0.2 & 0.01 & 0.02 & -0.02 & -0.07 & -0.11 & -0.06 & 0.02 & 0.03 & 0.1 & 0.12 & -0.15 \\
\hline 17. \# of patent ${ }^{\mathrm{a}}$ & 0.06 & 0.03 & 0.13 & 0.28 & 0.3 & 0.22 & 0.27 & 0.15 & 0.08 & 0.01 & 0.05 & 0.07 & 0.31 & -0.03 \\
\hline 18. \# of patent $\mathrm{t}^{\mathrm{b}}$ & -0.04 & 0.11 & 0.17 & 0.32 & 0.32 & 0.43 & 0.06 & 0.32 & 0.11 & -0.01 & 0.1 & -0.01 & 0.04 & 0.19 \\
\hline 19. Geographic distance & 0.08 & -0.15 & -0.16 & 0.03 & 0.04 & 0.01 & 0.02 & 0.11 & 0.1 & -0.14 & -0.2 & -0.15 & 0.14 & 0.06 \\
\hline 20. Common border & -0.07 & 0.17 & 0.15 & 0.11 & 0.14 & 0.12 & -0.01 & 0.03 & 0.06 & 0.14 & 0.13 & 0.07 & 0.18 & 0.18 \\
\hline 21. International IPR ${ }^{\mathrm{a}}$ & -0.16 & 0.24 & 0.25 & 0.14 & 0.16 & 0.13 & 0.2 & 0.15 & 0.06 & -0.13 & -0.11 & 0.23 & 0.55 & -0.13 \\
\hline 22. International IPR ${ }^{\mathrm{b}}$ & -0.15 & 0.22 & 0.2 & 0.08 & 0.08 & 0.11 & 0.18 & 0.22 & 0.02 & -0.12 & -0.08 & 0.14 & -0.12 & 0.49 \\
\hline 23. Legal origin & 0.07 & -0.06 & -0.01 & 0.05 & 0.01 & 0.04 & -0.03 & -0.04 & 0 & -0.19 & -0.33 & 0.3 & 0.2 & 0.18 \\
\hline 24. Cultural distance & 0.04 & -0.18 & -0.17 & 0 & 0.02 & 0.02 & 0.03 & 0.02 & -0.03 & 0.01 & 0.21 & -0.07 & -0.08 & -0.06 \\
\hline 25. Common language & -0.04 & 0.18 & 0.15 & -0.04 & -0.09 & -0.06 & -0.1 & -0.07 & -0.05 & -0.04 & -0.13 & 0.23 & 0.02 & 0.15 \\
\hline 26. Religious similarity & -0.01 & 0.18 & 0.18 & -0.04 & -0.08 & -0.06 & -0.01 & -0.05 & 0 & -0.17 & -0.37 & -0.05 & -0.04 & -0.02 \\
\hline 27. $\%$ of equity alliances & 0.24 & -0.13 & -0.09 & -0.01 & 0 & -0.04 & 0.13 & 0.13 & 0.03 & 0.03 & 0.02 & -0.08 & -0.04 & -0.05 \\
\hline
\end{tabular}




\begin{tabular}{|c|c|c|c|c|c|c|c|c|c|c|c|c|}
\hline & 15 & 16 & 17 & 18 & 19 & 20 & 21 & 22 & 23 & 24 & 25 & 26 \\
\hline 16. \# of firms within the same field of technology ${ }^{\mathrm{b}}$ & 0.37 & 1 & & & & & & & & & & \\
\hline 17. \# of patent ${ }^{\mathrm{a}}$ & -0.02 & -0.04 & 1 & & & & & & & & & \\
\hline 18. \# of patent ${ }^{\mathrm{b}}$ & -0.04 & -0.01 & 0.2 & 1 & & & & & & & & \\
\hline 19. Geographic distance & -0.15 & -0.12 & -0.01 & -0.02 & 1 & & & & & & & \\
\hline 20. Common border & -0.1 & -0.09 & 0.16 & 0.11 & 0.17 & 1 & & & & & & \\
\hline 21. International IPR ${ }^{\mathrm{a}}$ & 0.06 & 0.17 & 0.19 & 0.04 & 0.1 & 0.16 & 1 & & & & & \\
\hline 22. International IPR ${ }^{\mathrm{b}}$ & 0.16 & 0.02 & -0.01 & 0.08 & 0.08 & 0.13 & 0.26 & 1 & & & & \\
\hline 23. Legal origin & -0.1 & -0.16 & 0 & -0.12 & 0.18 & 0.24 & 0.17 & 0.08 & 1 & & & \\
\hline 24. Cultural distance & 0.02 & 0.01 & -0.05 & -0.01 & -0.29 & -0.41 & -0.13 & -0.15 & -0.33 & 1 & & \\
\hline 25. Common language & -0.09 & -0.11 & -0.06 & -0.05 & -0.13 & 0.36 & -0.07 & -0.08 & 0.51 & -0.23 & 1 & \\
\hline 26. Religious similarity & -0.03 & -0.04 & -0.02 & -0.11 & 0.15 & 0.28 & 0.05 & 0.01 & 0.44 & -0.55 & 0.18 & 1 \\
\hline 27. $\%$ of equity alliances & -0.12 & -0.12 & 0.05 & -0.02 & 0.04 & -0.05 & -0.07 & -0.1 & -0.03 & 0.06 & 0.01 & -0.02 \\
\hline
\end{tabular}

${ }^{a}$ Alliance firm with lower national trust in an alliance dyad

${ }^{\mathrm{b}}$ Alliance firm with higher national trust in an alliance dyad 
TABLE 2

NATIONAL TRUST MATRIX

\begin{tabular}{|c|c|c|c|c|c|c|c|c|c|c|c|c|c|}
\hline \multirow[t]{2}{*}{ Countries of origin } & \multicolumn{12}{|c|}{ Countries of target } & \multirow[b]{2}{*}{ Average } \\
\hline & 1 & 2 & 3 & 4 & 5 & 6 & 7 & 8 & 9 & 10 & 11 & 12 & \\
\hline 1. Austria & 3.56 & 2.95 & 2.61 & 2.95 & 2.95 & 2.94 & 2.62 & 3.09 & 2.55 & 2.43 & 2.58 & 3.05 & 2.82 \\
\hline 2. Belgium & 2.83 & 3.28 & 2.84 & 3.01 & 2.90 & 2.92 & 2.92 & 2.75 & 2.75 & 2.40 & 2.59 & 2.99 & 2.80 \\
\hline 3. United Kingdom & 2.89 & 2.91 & 3.29 & 3.13 & 3.16 & 2.98 & 2.32 & 2.62 & 2.61 & 2.51 & 2.47 & 3.03 & 2.82 \\
\hline 4. Denmark & 3.22 & 3.18 & 3.22 & 3.39 & 3.33 & 3.20 & 2.86 & 3.12 & 3.02 & 2.53 & 2.66 & 3.41 & 3.06 \\
\hline 5. Netherlands & 2.90 & 3.18 & 3.00 & 3.29 & 3.28 & 3.25 & 2.72 & 2.84 & 2.80 & 2.35 & 2.64 & 3.34 & 2.95 \\
\hline 6. Finland & 3.29 & 3.07 & 3.18 & 3.30 & 3.14 & 3.69 & 2.92 & 2.89 & 2.92 & 2.51 & 2.61 & 3.35 & 3.05 \\
\hline 7. France & 2.70 & 3.07 & 2.55 & 2.96 & 2.94 & 2.91 & 3.18 & 2.74 & 2.72 & 2.43 & 2.68 & 2.99 & 2.80 \\
\hline 8. Germany & 2.98 & 2.84 & 2.69 & 2.97 & 2.90 & 2.85 & 2.85 & 3.50 & 2.59 & 2.36 & 2.66 & 2.99 & 2.81 \\
\hline 9. Ireland & 2.93 & 2.93 & 2.81 & 2.99 & 3.00 & 2.92 & 2.81 & 2.78 & 3.33 & 2.65 & 2.64 & 2.92 & 2.85 \\
\hline 10. Italy & 2.66 & 2.64 & 2.51 & 2.70 & 2.77 & 2.78 & 2.66 & 2.63 & 2.37 & 2.80 & 2.64 & 2.89 & 2.64 \\
\hline 11. Spain & 2.65 & 2.73 & 2.31 & 2.73 & 2.85 & 2.71 & 2.37 & 2.66 & 2.57 & 2.61 & 3.32 & 2.84 & 2.67 \\
\hline 12. Sweden & 3.53 & 3.23 & 3.43 & 3.57 & 3.33 & 3.49 & 3.04 & 3.13 & 3.26 & 2.81 & 2.86 & 3.59 & 3.25 \\
\hline Average & 2.90 & 2.96 & 2.85 & 3.05 & 3.00 & 2.95 & 2.79 & 2.84 & 2.77 & 2.53 & 2.68 & 3.01 & \\
\hline
\end{tabular}


TABLE 3

HGLM ANALYSIS RESULTS

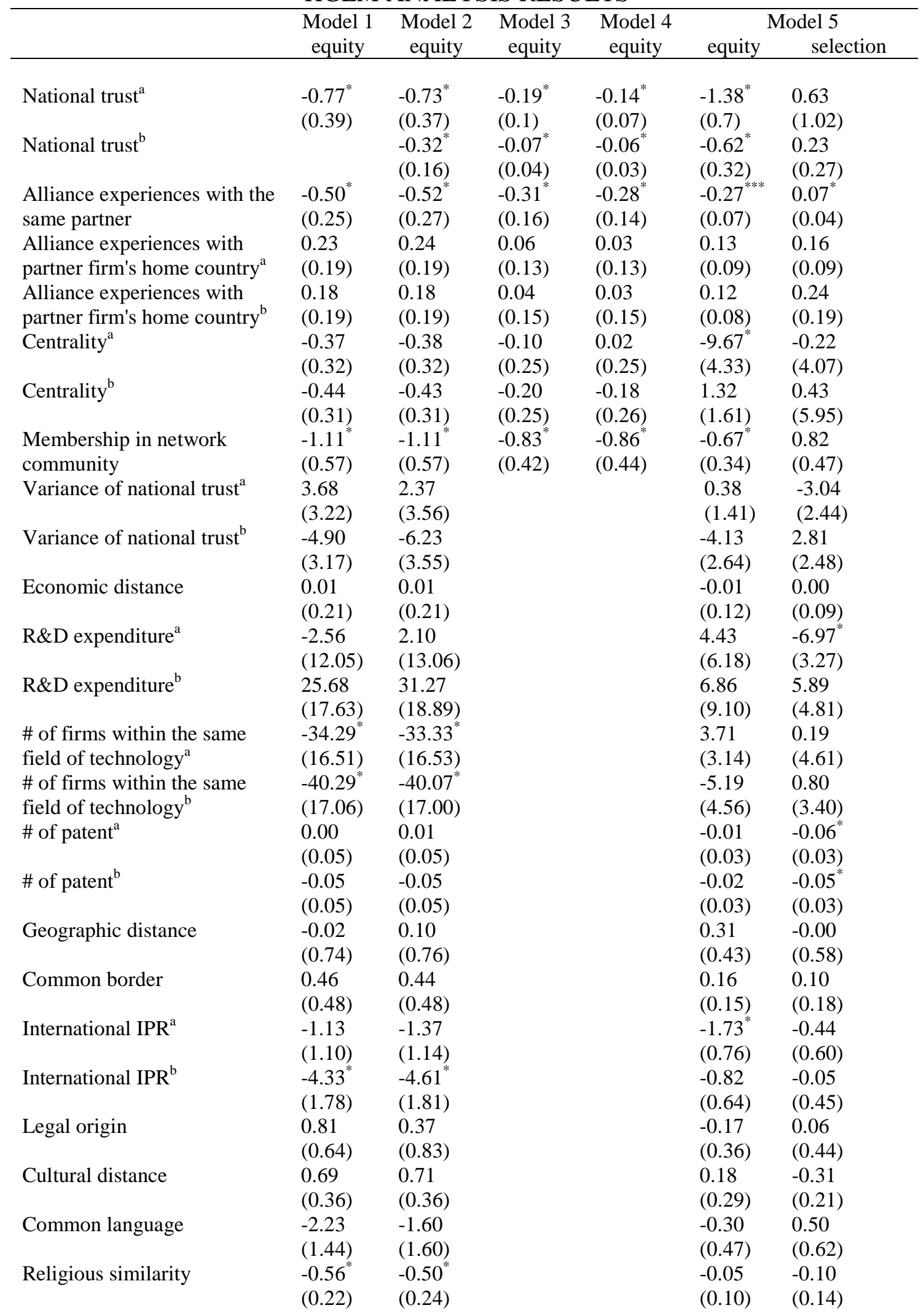




\begin{tabular}{|c|c|c|c|c|c|c|}
\hline$\%$ of equity alliances & $\begin{array}{l}0.40 \\
(0.74)\end{array}$ & $\begin{array}{l}0.38 \\
(0.74)\end{array}$ & & & $\begin{array}{l}0.99 \\
(0.79)\end{array}$ & $\begin{array}{l}1.05 \\
(0.88)\end{array}$ \\
\hline Constant & $\begin{array}{l}26.21^{*} \\
(10.78)\end{array}$ & $\begin{array}{l}29.75^{*} \\
(11.63)\end{array}$ & $\begin{array}{r}3.60^{*} \\
(1.51)\end{array}$ & $\begin{array}{l}3.58^{*} \\
(1.51)\end{array}$ & $\begin{array}{l}20.10^{* *} \\
(7.63)\end{array}$ & $\begin{array}{l}178.86 \\
(22.53)\end{array}$ \\
\hline Year fixed effect & Yes & Yes & Yes & Yes & Yes & Yes \\
\hline Country fixed effect & No & No & Yes & Yes & No & No \\
\hline Field of technology dummies & Yes & Yes & Yes & Yes & Yes & Yes \\
\hline
\end{tabular}


TABLE 4

HGLM INTERACTION ANALYSIS RESULTS

\begin{tabular}{|c|c|c|c|c|}
\hline & $\begin{array}{l}\text { Model } 6 \\
\text { equity }\end{array}$ & $\begin{array}{l}\text { Model } 7 \\
\text { equity }\end{array}$ & $\begin{array}{l}\text { Model } 8 \\
\text { equity }\end{array}$ & $\begin{array}{l}\text { Model } 9 \\
\text { equity }\end{array}$ \\
\hline National trust $^{\mathrm{a}}(\mathrm{A})$ & $-0.21^{*}$ & $-0.11^{*}$ & $-0.24^{*}$ & $-0.2^{*}$ \\
\hline National trust ${ }^{\mathrm{b}}(\mathrm{B})$ & $\begin{array}{l}-0.08^{*} \\
(0.04)\end{array}$ & $\begin{array}{l}-0.09^{*} \\
(0.05)\end{array}$ & $\begin{array}{l}-0.09^{*} \\
(0.05)\end{array}$ & $\begin{array}{l}-0.1^{*} \\
(0.05)\end{array}$ \\
\hline $\begin{array}{l}\text { Alliance experiences with the } \\
\text { same partner (C) }\end{array}$ & $\begin{array}{l}-0.07^{*} \\
(0.04)\end{array}$ & $\begin{array}{l}-0.04^{*} \\
(0.02)\end{array}$ & $\begin{array}{l}-0.04^{*} \\
(0.02)\end{array}$ & $\begin{array}{l}-0.1^{*} \\
(0.05)\end{array}$ \\
\hline $\begin{array}{l}\text { Alliance experiences with } \\
\text { partner firm's home country }\end{array}$ & $\begin{array}{l}0.01 \\
(0.02)\end{array}$ & $\begin{array}{l}0.01 \\
(0.02)\end{array}$ & $\begin{array}{l}0.01 \\
(0.02)\end{array}$ & $\begin{array}{l}0.01 \\
(0.02)\end{array}$ \\
\hline $\begin{array}{l}\text { Alliance experiences with } \\
\text { partner firm's home country }\end{array}$ & $\begin{array}{l}0.00 \\
(0.02)\end{array}$ & $\begin{array}{l}0.00 \\
(0.02)\end{array}$ & $\begin{array}{l}0.00 \\
(0.02)\end{array}$ & $\begin{array}{l}0.01 \\
(0.02)\end{array}$ \\
\hline Centrality $^{\mathrm{a}}(\mathrm{D})$ & $\begin{array}{l}-0.01 \\
(0.04)\end{array}$ & $\begin{array}{l}-0.02 \\
(0.04)\end{array}$ & $\begin{array}{l}-0.01 \\
(0.04)\end{array}$ & $\begin{array}{l}-0.02 \\
(0.04)\end{array}$ \\
\hline Centrality $^{\mathrm{b}}(\mathrm{E})$ & $\begin{array}{l}-0.02 \\
(0.04)\end{array}$ & $\begin{array}{l}-0.02 \\
(0.04)\end{array}$ & $\begin{array}{l}-0.02 \\
(0.04)\end{array}$ & $\begin{array}{l}-0.02 \\
(0.04)\end{array}$ \\
\hline $\begin{array}{l}\text { Membership in network } \\
\text { community (F) }\end{array}$ & $\begin{array}{l}-0.14 \\
(0.08)\end{array}$ & $\begin{array}{l}-0.14 \\
(0.08)\end{array}$ & $\begin{array}{l}-0.14 \\
(0.08)\end{array}$ & $\begin{array}{l}-0.18 \\
(0.08)\end{array}$ \\
\hline $\mathrm{A} \times \mathrm{C}$ & $\begin{array}{l}0.08^{* *} \\
(0.03)\end{array}$ & & & $\begin{array}{l}0.09^{* *} \\
(0.03)\end{array}$ \\
\hline $\mathrm{B} \times \mathrm{C}$ & $\begin{array}{l}0.01^{*} \\
(0.01)\end{array}$ & & & $\begin{array}{l}0.06^{*} \\
(0.04)\end{array}$ \\
\hline$A \times D$ & & $\begin{array}{l}-0.05 \\
(0.03)\end{array}$ & & $\begin{array}{l}-0.05 \\
(0.03)\end{array}$ \\
\hline $\mathrm{B} \times \mathrm{E}$ & & $\begin{array}{l}-0.04 \\
(0.04)\end{array}$ & & $\begin{array}{l}-0.03 \\
(0.04)\end{array}$ \\
\hline$A \times F$ & & & $\begin{array}{l}0.07^{*} \\
(0.04)\end{array}$ & $\begin{array}{l}0.1^{*} \\
(0.05)\end{array}$ \\
\hline $\mathrm{B} \times \mathrm{F}$ & & & $\begin{array}{l}0.10^{*} \\
(0.06)\end{array}$ & $\begin{array}{l}0.06^{*} \\
(0.04)\end{array}$ \\
\hline Constant & $\begin{array}{l}0.75 \\
(0.44)\end{array}$ & $\begin{array}{l}0.80 \\
(0.44)\end{array}$ & $\begin{array}{l}0.74 \\
(0.44)\end{array}$ & $\begin{array}{l}0.77 \\
(0.43)\end{array}$ \\
\hline Year fixed effect & Yes & Yes & Yes & Yes \\
\hline Country fixed effect & Yes & Yes & Yes & Yes \\
\hline Field of technology dummies & Yes & Yes & Yes & Yes \\
\hline
\end{tabular}


FIGURE 1

THE EFFECT OF NATIONAL TRUST INTERACTED WITH ALLIANCE EXPERIENCES WITH THE SAME PARTNER

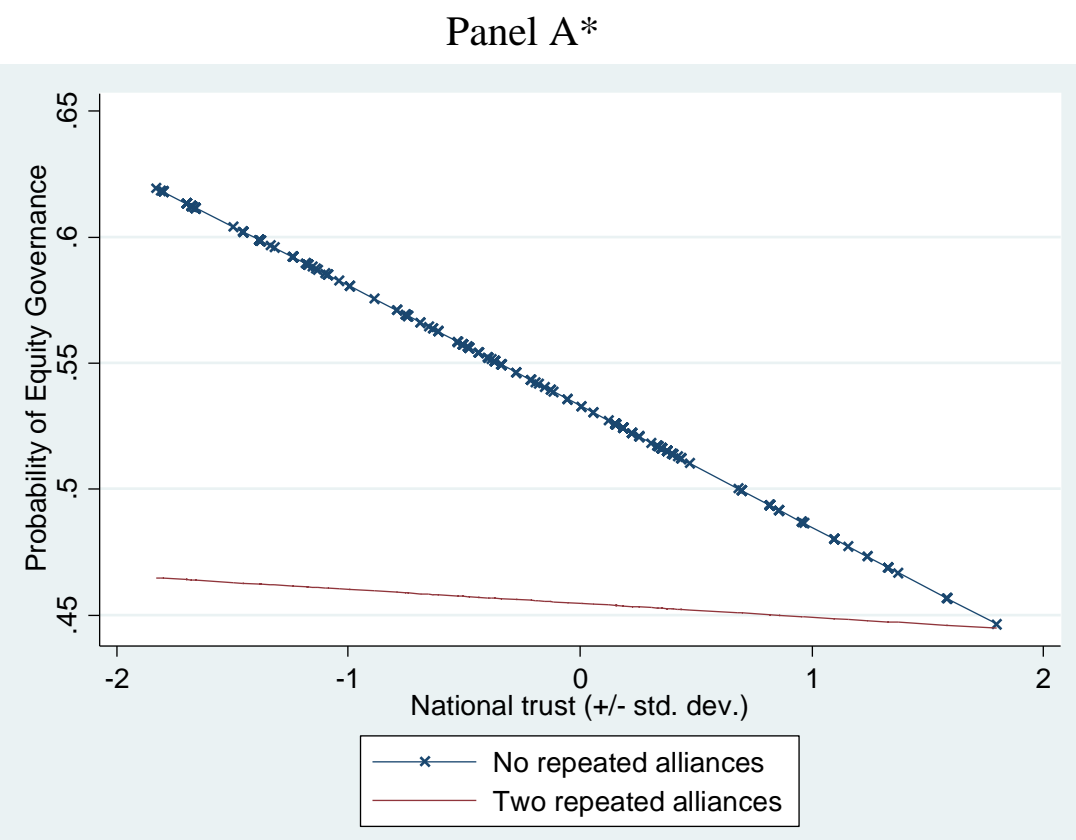

*The national trust measure of the lower national trust partner

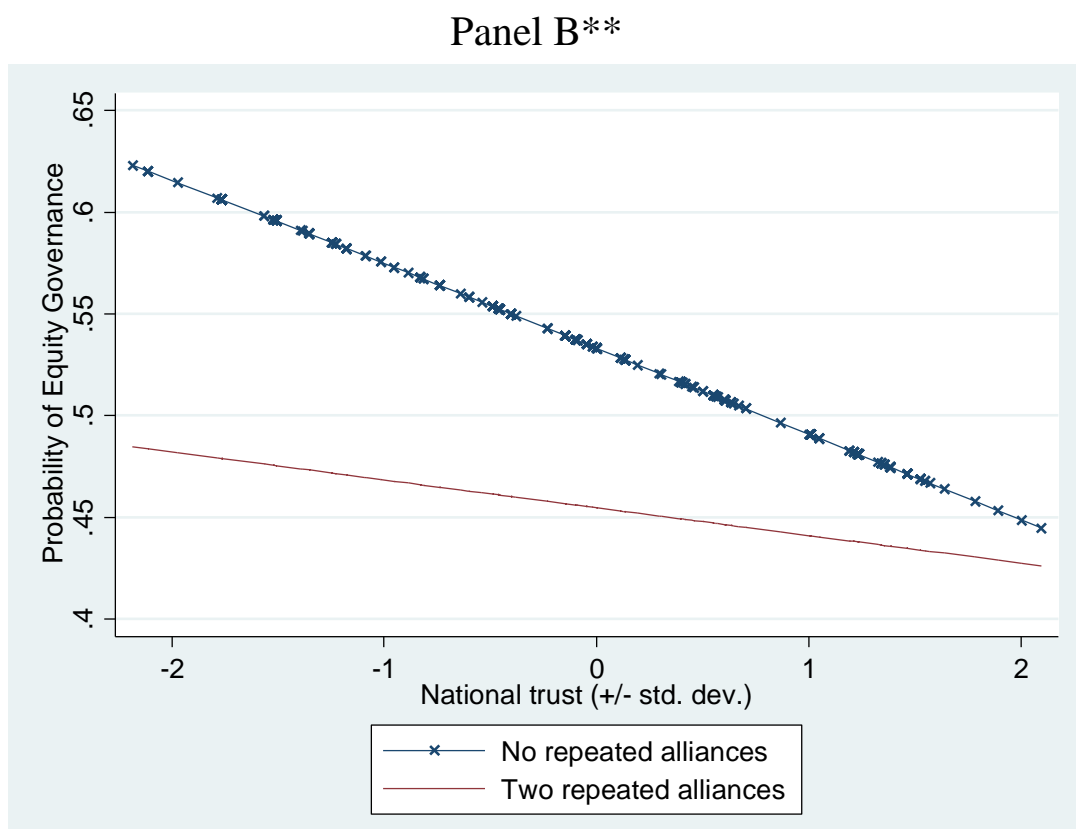

**The national trust measure of the higher national trust partner 
FIGURE 2

THE EFFECT OF NATIONAL TRUST INTERACTED WITH MEMBERSHIP IN NETWORK COMMUNITY

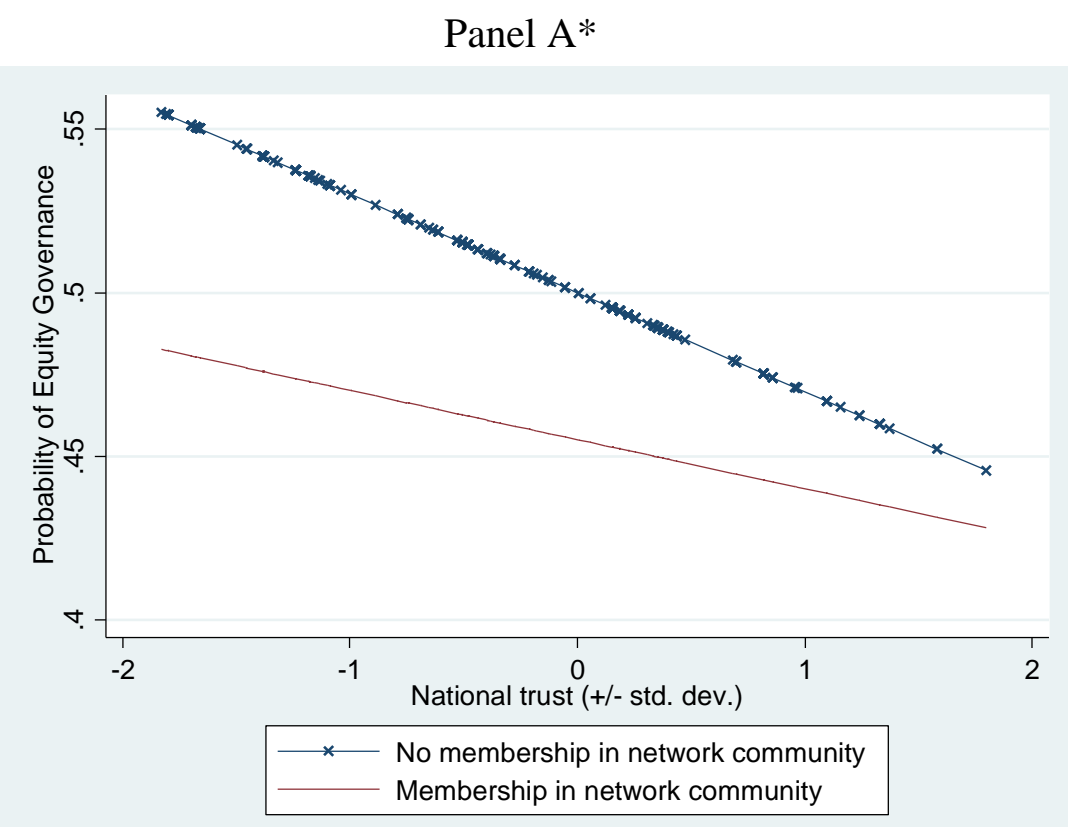

*The national trust measure of the lower national trust partner

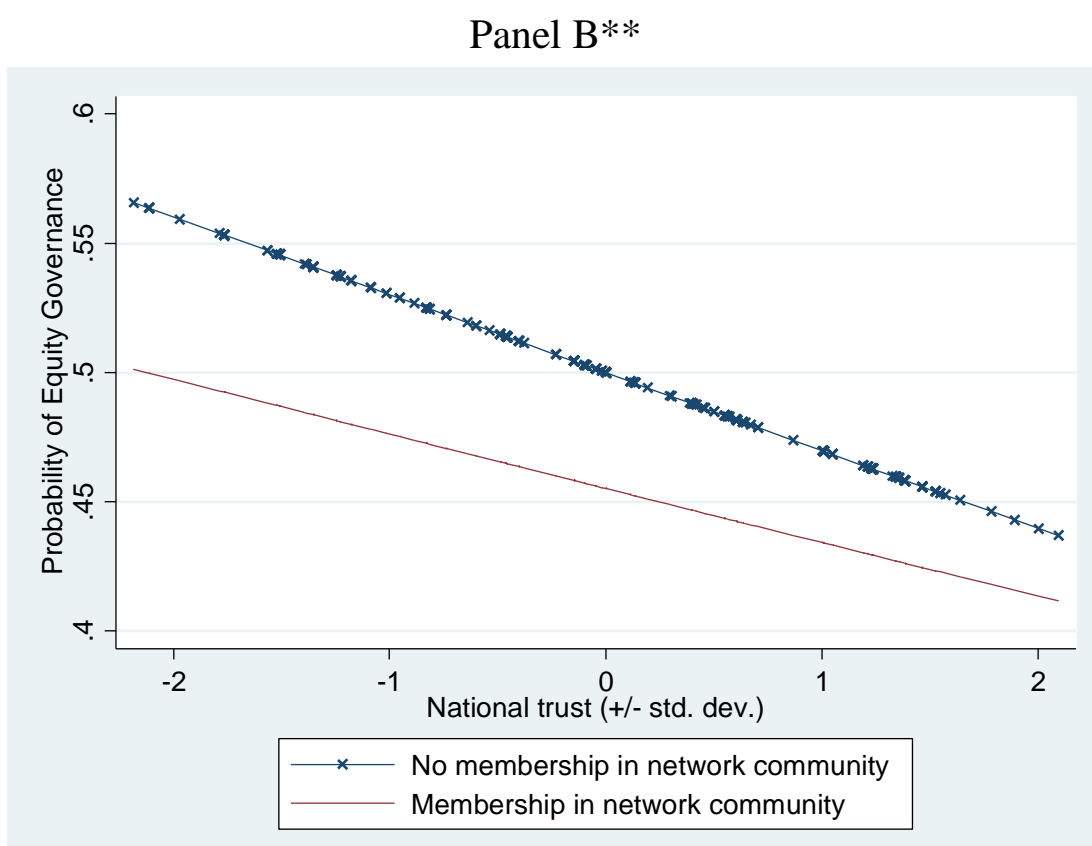

**The national trust measure of the higher national trust partner 


\section{REFERENCES}

Adler, P. S. \& Kwon, S. W. 2002. Social capital: Prospects for a new concept. Academy of management review, 27(1): 17-40.

Ahuja, G. 2000. Collaboration Networks, Structural Holes, and Innovation: A Longitudinal Study. Administrative Science Quarterly, 45(3): 425-55.

Aiken, L. S. \& West, S. G. 1991. Multiple regression: Testing and interpreting interactions. Newbury Park, CA: Sage.

Al-Sulaiti, K. I. \& Baker, M. J. 1998. Country of origin effects: a literature review. Marketing Intelligence \& Planning, 16(3): 150-99.

Allison, P. D. 1999. Multiple regression : a primer. Thousand Oaks, Calif.: Pine Forge Press.

Allport, G. W. 1954. The nature of prejudice: Addison-Wesley.

Amburgey, T. L. \& Miner, A. S. 1992. Strategic momentum: The effects of repetitive, positional and contextual momentum on merger activity. Strategic Management Journal, 13(5): 335-48.

Anand, B. N. \& Khanna, T. 2000. Do firms learn to create value? The case of alliances. Strategic Management Journal, 21(3): 295-315.

Archibugi, D. \& Coco, A. 2005. Measuring technological capabilities at the country level: A survey and a menu for choice. Research Policy, 34(2): 175-94.

Arikan, I. \& Shenkar, O. 2013. National Animosity and Cross-border Alliances. Academy of Management Journal.

Arino, A., de la Torre, J., \& Ring, P. S. 2001. Relational quality: Managing trust in corporate alliances. California Management Review, 44(1): 109-31.

Au, K. Y. 1999. Intra-Cultural Variation: Evidence and Implications for International Business. Journal of International Business Studies, 30(4): 799-812.

Barnett, M. L. \& Pollock, T. G. 2012. The Oxford handbook of corporate reputation. Oxford: Oxford University Press.

Bazerman, M. H. \& Moore, D. A. 2013. Judgment in managerial decision making. 8th ed. New York: Wiley.

Becerra, M. \& Gupta, A. K. 2003. Perceived Trustworthiness within the Organization: The Moderating Impact of Communication Frequency on Trustor and Trustee Effects. Organization Science, 14(1): 32-44.

Belsley, D. A., Kuh, E., \& Welsch, R. E. 1980. Regression diagnostics : identifying influential data and sources of collinearity. New York: Wiley. 
Berry, H., Guillén, M. F., \& Zhou, N. 2010. An institutional approach to cross-national distance. Journal of International Business Studies, 41(9): 1460-80.

Bodenhausen, G. V., Kang, S. K., \& Peery, D. 2012. Social Categorization and the Perception of Social Groups. The SAGE Handbook of Social Cognition: 311.

Borgatti, S., Everett, M., \& Freeman, L. 2002. UCINET 6 for Windows. Harvard: Analytic Technologies.

Bornhorst, F., Ichino, A., Schlag, K., \& Winter, E. 2004. Trust and trustworthiness among Europeans: South-North comparison: Centre for Economic Policy Research.

Brass, D. J., Galaskiewicz, J., Greve, H. R., \& Tsai, W. P. 2004. Taking stock of networks and organizations: A multilevel perspective. Academy of Management Journal, 47(6): 795-817.

Brewer, M. B. 1988. A Dual Model of Impression Formation.In Robert S. Wyer, Jr. \& Thomas K. Srull, (Eds.), Advances in social cognition. Hillsdale, N.J.: L. Erlbaum.

Brewer, M. B. \& Miller, N. 1984. Beyond the contact hypothesis: Theoretical perspectives on desegregation.In Miller, N. \& M. B. Brewer, (Eds.), Groups in contact: The psychology of desegregation. Orlando, FL: Academic Press.

Brief, A. P., Butz, R. M., \& Deitch, E. A. 2005. Organizations as reflections of their environments: The case of race composition.In Dipboye, R.L. \& A. Colella, (Eds.), Discrimination at work: The psychological and organizational bases. Mahwah, N.J.: Lawrence Erlbaum.

Brief, A. P., Umphress, E. E., Dietz, J., Butz, R. M., Burrows, J., \& Scholten, L. 2005. Community matters: Realistic group conflict theory and the impact of diversity. Academy of Management Journal, 48(5): 830-44.

Bromiley, P. \& Cummings, L. L. 1995. Transactions costs in organizations with trust. Research on negotiation in organizations, 5: 219-47.

Burns, P., Myers, A., \& Kakabadse, A. 1995. Are national stereotypes discriminating? European Management Journal, 13(2): 212-17.

Burt, R. S. 2000. The Network Structure of Social Capital.In Sutton, R.I. \& B.M. Staw, (Eds.), Research in Organizational Behavior: JAI Press.

Burt, R. S. 1992. Structural holes: The social structure of competition. Cambridge, MA: Harvard University Press.

Burt, R. S. \& Knez, M. 1995. Kinds of third-party effects on trust. Rationality and Society, 7(3): 255-92. 
Carpenter, M. A., Pollock, T. G., \& Leary, M. M. 2003. Testing a model of reasoned risk-taking: governance, the experience of principals and agents, and global strategy in high-technology IPO firms. Strategic Management Journal, 24(9): 803-20.

Casciaro, T. 2003. Determinants of governance structure in alliances: the role of strategic, task and partner uncertainties. Industrial and Corporate Change, 12(6): 1223-51.

Coleman, J. S. 1992. The rational reconstruction of society. American Sociological Review, 58(1): 1 - 15.

Colombo, M. G. 2003. Alliance form: A test of the contractual and competence perspectives. Strategic Management Journal, 24(12): 1209-29.

Connelly, B. L., Miller, T., \& Devers, C. E. 2012. Under a cloud of suspicion: trust, distrust, and their interactive effect in interorganizational contracting. Strategic Management Journal, 33(7): 820-33.

Das, T. K. \& Teng, B. S. 1998. Between trust and control: Developing confidence in partner cooperation in alliances. Academy of Management Review, 23(3): 491-512.

Dietz, J., Robinson, S. L., Folger, R., Baron, R. A., \& Schulz, M. 2003. The Impact of Community Violence and an Organization's Procedural Justice Climate on Workplace Aggression. Academy of Management Journal, 46(3): 317-26.

Djankov, S., Porta, R. L., López-de-Silanes, F., \& Shleifer, A. 2003. Courts: The Lex Mundi Project. Quarterly Journal of Economics, 118(2): 453-517.

Doney, P. M. \& Cannon, J. P. 1997. An examination of the nature of trust in buyer-seller relationships. the Journal of Marketing: 35-51.

Dyer, J. H. \& Chu, W. 2000. The determinants of trust in supplier-automaker relationships in the US, Japan and Korea. Journal of International Business Studies, 31(2): 259-85.

Ertug, G., Cuypers, I. R. P., Noorderhaven, N. G., \& Bensaou, B. M. 2013. Trust between international joint venture partners: Effects of home countries. J Int Bus Stud(4): 263-82.

Fazio, R. H. \& Zanna, M. P. 1981. Direct experience and attitude-behavior consistency.In Berkowitz, L., (Ed.), Advances in experimental social psychology. New York: Academic Press.

Ferrin, D. L., Dirks, K. T., \& Shah, P. P. 2006. Direct and indirect effects of third-party relationships on interpersonal trust. Journal of Applied Psychology, 91(4): 870-83.

Ferrin, D. L. \& Gillespie, N. 2010. Trust differences across national-societal cultures: Much to do, or much ado about nothing. Organizational trust: A cultural perspective: 42-86.

Finkelstein, S., Hambrick, D., \& Cannella, A. A. 2009. Strategic leadership: Theory and research on executives, top management teams, and boards: Oxford University Press. 
Fiske, S. T. \& Neuberg, S. L. 1990. A continuum of impression formation, from category-based to individuating processes: Influences of information and motivation on attention and interpretation.In Zanna, M.P., (Ed.), Advances in experimental social psychology. San Diego: Academic.

Fiske, S. T. \& Taylor, S. E. 1984. Social cognition. Reading, Mass.: Addison-Wesley Pub. Co.

Foddy, M. \& Yamagishi, T. 2009. Group-based trust.In Cook, Karen S., Margaret Levi, \& Russell Hardin, (Eds.), Whom can we trust? How groups, networks, and institutions make trust possible. New York: Russell Sage Foundation.

Fombrun, C. J. 1996. Reputation : realizing value from the corporate image. Boston, Mass.: Harvard Business School Press.

Freeman, L. 1979. Centrality in social networks: Conceptual clarification. Social Networks, 1: 215-39.

Gambetta, D. \& Hamill, H. 2005. Streetwise: how taxi drivers establish their customers' trustworthiness. New York: Russell Sage.

García-Canal, E. 1996. Contractual Form in Domestic and International Strategic Alliances. Organization Studies, 17(5): 773-94.

Gargiulo, M., Ertug, G., \& Galunic, C. 2009. The Two Faces of Control: Network Closure and Individual Performance among Knowledge Workers. Administrative Science Quarterly, 54(2): 299-333.

Girvan, M. \& Newman, M. E. J. 2002. Community structure in social and biological networks. Proceedings of the national academy of sciences, 99(12): 7821-26.

Globerman, S. \& Nielsen, B. B. 2007. Equity versus non-equity international strategic alliances involving Danish firms: An empirical investigation of the relative importance of partner and host country determinants. Journal of International Management, 13(4): 449-71.

Gnyawali, D. R. \& Madhavan, R. 2001. Cooperative networks and competitive dynamics: A structural embeddedness perspective. Academy of Management Review, 26(3): 431-45.

Golub, G. H. \& Van Loan, C. F. 1996. Matrix computations. 3rd ed. Baltimore: Johns Hopkins University Press.

Gomes-Casseres, B. 1994. Group versus group: How alliance networks compete. Harvard Business Review, 72: 62-62.

Greve, H. R. 2009. Bigger and Safer: The Diffusion of Competitive Advantage. Strategic Management Journal, 30(1): 1-23.

Guiso, L., Sapienza, P., \& Zingales, L. 2009. Cultural Biases in Economic Exchange. Quarterly Journal of Economics, 124(3): 1095-131. 
Guiso, L., Sapienza, P., \& Zingales, L. 2006. Does culture affect economic outcomes? Journal of Economic Perspectives, 20(2): 23-48.

Gulati, R. 1998. Alliances and networks. Strategic Management Journal, 19(4): 293-317.

Gulati, R. 1995. Does Familiarity Breed Trust? The Implications of Repeated Ties for Contractual Choice in Alliances. Academy of Management Journal, 38(1): 85-112.

Gulati, R. \& Gargiulo, M. 1999. Where do Interorganizational networks come from? American Journal of Sociology, 104: 1439-93.

Guo, G. \& Zhao, H. 2000. Multilevel modeling for binary data. Annual Review of Sociology, 26: 441-62.

Hagedoorn, J. 2002. Inter-firm R\&D partnerships: an overview of major trends and patterns since 1960. Research Policy, 31(4): 477-92.

Hagedoorn, J. 2006. Understanding the Cross-Level Embeddedness of Interfirm Partnership Formation. The Academy of Management Review, 31(3): 670-80.

Hagedoorn, J., Cloodt, D., \& Kranenburg, H. v. 2005. Intellectual Property Rights and the Governance of International R\&D Partnerships. Journal of International Business Studies, 36(2): 175-86.

Hambrick, D. C. 1989. Guest editor's introduction: Putting top managers back in the strategy picture. Strategic Management Journal, 10(S1): 5-15.

Hennart, J.-F. 1991. The transaction cost theory of joint ventures: An empirical study of Japanese subsidiaries in the USA. Management Science, 37: 483-97.

Hennart, J.-F. 1988. A Transaction Costs Theory of Equity Joint Ventures. Strategic Management Journal, 9(4): 361-74.

Higgins, E. T. \& King, G. 1981. Accessibility of social constructs: Information-processing consequences of individual and contextual variability. Personality, Cognition, and Social Interaction, 69: 121.

Hofstede, G. 1980. Culture's consequences: International differences in work-related values. Beverly Hills, CA: Sage.

Hsu, G. \& Elsbach, K. D. 2013. Explaining Variation in Organizational Identity Categorization. Organization Science, 24(4): 996-1013.

Huber, E. \& Stephens, J. D. 1993. Political Parties and Public Pensions: A Quantitative Analysis. Acta Sociologica, 36(4): 309-25.

Inkpen, A. C. \& Currall, S. C. 2004. The Coevolution of Trust, Control, and Learning in Joint Ventures. Organization Science, 15(5): 586-99. 
Inkpen, A. C. \& Currall, S. C. 1997. International joint venture trust: An empirical examination.In Beamish, P. W. \& J. P. Killing, (Eds.), Cooperative Strategies: North American perspectives. San Francisco: New Lexignton Press.

Jaccard, J., Turrisi, R., \& Wan, C. K. 1990. Interaction effects in multiple regression. Newbury Park, CA: Sage.

Janowicz, M. \& Noorderhaven, N. 2006. Levels of inter-organizational trust: conceptualization and measurement. Handbook of trust research: 264.

Kogut, B. 1988. Joint ventures: Theoretical and empirical perspectives. Strategic Management Journal, 9(4): 319-32.

Kogut, B. \& Singh, H. 1988. The effect of national culture on the choice of entry mode. Journal of International Business Studies, 19: 411-32.

Kostova, T. \& Zaheer, S. 1999. Organizational Legitimacy under Conditions of Complexity: The Case of the Multinational Enterprise. Academy of Management Review, 24(1): 64-81.

Kramer, R. M. 1999. Trust and distrust in organizations: Emerging perspectives, enduring questions. Annual Review of Psychology, 50: 569-98.

Kwon, S. W., Heflin, C., \& Ruef, M. 2013. Community Social Capital and Entrepreneurship. American Sociological Review, 78(6): 980-1008.

Levin, R. C., Klevorick, A. K., Nelson, R. R., \& Winter, S. G. 1987. Appropriating the Returns from Industrial Research and Development. Brookings Papers of Economic Activity(No. 3): 783831 (including "Comments and Discussion" pp. 21-31).

Li, D., Eden, L., Hitt, M. A., \& Ireland, R. D. 2008. Friends, acquaintances, or strangers? Partner selection in R\&D alliances. Academy of Management Journal, 51(2): 315-34.

Li, N., Boulding, W., \& Stael, R. 2010. General alliance experience, uncertainty, and marketing alliance governance mode choice. Journal of the Academy of Marketing Science, 38(2): 141-58.

Locksley, A., Borgida, E., Brekke, N., \& Hepburn, C. 1980. Sex stereotypes and social judgment. Journal of Personality and Social Psychology, 39(5): 821-31.

MacDuffie, J. P. 2010. Inter-organizational trust and the dynamics of distrust. Journal of International Business Studies, 42(1): 35-47.

Mackie, G. 2001. Patterns of social trust in Western Europe and their genesis.In Cook, Karen S., (Ed.), Trust in Society. N.Y.: Russell Sage Foundation.

Macrae, C. N. \& Bodenhausen, G. V. 2000. Social Cognition: Thinking Categorically about Others. Annual Review of Psychology, 51(1): 93-120. 
Maheswaran, D. 1994. Country of Origin as a Stereotype: Effects of Consumer Expertise and Attribute Strength on Product Evaluations. Journal of Consumer Research, 21(2): 354-65.

Markus, H. \& Zajonc, R. B. 1985. The cognitive perspective in social psychology. Handbook of social psychology, 1: 137-230.

Mayer, K. J. \& Argyres, N. S. 2004. Learning to contract: Evidence from the personal computer industry. Organization Science, 15(4): 394-410.

Mayer, R. C., Davis, J. H., \& Schoorman, F. D. 1995. An integrative model of organizational trust. Academy of Management Review, 20(13): 709-34.

McEvily, W., Weber, R. A., Bicchieri, C., \& Ho, V. 2006. Can Groups Be Trusted? An Experimental Study of Collective Trust.In Bachmann, Reinhard \& Akbar Zaheer, (Eds.), Handbook of trust research. Cheltenham, UK ; Northampton, MA: Edward Elgar.

McKnight, D. H., Cummings, L. L., \& Chervany, N. L. 1998. Initial Trust Formation in New Organizational Relationships. Academy of Management Review, 23(3): 473-90.

Menard, S. W. 1995. Applied logistic regression analysis. Thousand Oaks, Calif.: Sage Publications.

Meyerson, D., Weick, K. E., \& Kramer, R. M. 1996. Swift trust and temporary systems.In Kramer, R. M. \& T. R. Tyler, (Eds.), Trust in organizations. Thousand Oaks, CA: Sage.

Mohr, J. \& Spekman, R. 1994. Characteristics of Partnership Success: Partnership Attributes, Communication Behavior, and Conflict Resolution Techniques. Strategic Management Journal, 15(2): 135-52.

Morris, M. W., Leung, K., Ames, D., \& Lickel, B. 1999. Views from inside and outside: Integrating emic and etic insights about culture and justice judgment. Academy of Management Review, 24(4): 781-96.

Mowery, D. C., Oxley, J. E., \& Silverman, B. S. 1996. Strategic alliances and interfirm knowledge transfer. Strategic Management Journal, 17: 77-91.

Muethel, M. \& Bond, M. H. 2013. National context and individual employees' trust of the outgroup: The role of societal trust. Journal of International Business Studies, 44(4): 312-33.

Neter, J., Wasserman, W., \& Kutner, M. H. 1990. Applied linear statistical models: regression, analysis of variance, and experimental designs. 3rd ed. Homewood, IL: Irwin.

Newman, M. E. J. 2003. Properties of highly clustered networks. Physical Review E, 68(2): 026121.

Nisbett, R. E., Zukier, H., \& Lemley, R. E. 1981. The dilution effect: Nondiagnostic information weakens the implications of diagnostic information. Cognitive Psychology, 13(2): 248-77. 
Oxley, J. E. 1997. Appropriability hazards and governance in strategic alliances: A transaction cost approach. Journal of Law Economics \& Organization, 13(2): 387-409.

Oxley, J. E. 1999. Institutional environment and the mechanisms of governance: The impact of intellectual property protection on the structure of inter-firm alliances. Journal of Economic Behavior and Organization, 38: 283-309.

Paluck, E. L. \& Green, D. P. 2009. Prejudice Reduction: What Works? A Review and Assessment of Research and Practice. Annual Review of Psychology, 60(1): 339-67.

Park, S. H. \& Ungson, G. R. 1997. The effect of national culture, organizational complementarity, and economic motivation on joint venture dissolution. Academy of Management Journal, 40(2): 279-307.

Park, S. H. \& Ungson, G. R. 2001. Interfirm Rivalry and Managerial Complexity: A Conceptual Framework of Alliance Failure. Organization Science, 12(1): 37-53.

Parkhe, A. 1998. Building Trust in International Alliances. Journal of World Business, 33(4): 417-37.

Pettigrew, A. M. 1979. On Studying Organizational Cultures. Administrative Science Quarterly, 24(4): 570 .

Pisano, G. P. 1989. Using equity participation to support exchange: Evidence from the biotechnology industry. Journal of Law, Economics, and Organization, 1: 109-25.

Poppo, L., Zhou, K. Z., \& Ryu, S. M. 2008. Alternative origins to interorganizational trust: An interdependence perspective on the shadow of the past and the shadow of the future.

Organization Science, 19(1): 39-55.

Powell, W. W. 1990. Neither Market nor Hierarchy: Network Forms of Organization, Research in Organizational Behavior.

Powell, W. W., Koput, K. W., \& Smith-Doer, L. 1996. Interorganizational collaboration and the locus of innovation: Networks of learning in biotechnology. Administrative Science Quarterly, 41(1): 116.

Putnam, R. D. 1993. The prosperous community: Social capital and public life. American Prospect, 13: 35-42.

Raub, W. \& Weesie, J. 1990. Reputation and efficiency in social interactions: An example of network effects. American Journal of Sociology, 96(3): 626-54.

Raudenbush, S. W. \& Bryk, A. S. 2002. Hierarchical linear models: Applications and data analysis methods. 2nd ed. Thousand Oaks, CA: Sage Publications.

Ring, P. S. \& Van de Ven, A. H. 1992. Structuring Cooperative Relationships Between Organizations. Strategic Management Journal, 13: 483-98. 
Rosenkopf, L. \& Almeida, P. 2003. Overcoming local search through alliances and mobility. Management Science, 49(6): 751-66.

Schilling, M. A. 2009. Understanding the alliance data. Strategic Management Journal, 30(3): 233-60.

Schilling, M. A. \& Phelps, C. C. 2007. Interfirm Collaboration Networks: The Impact of LargeScale Network Structure on Firm Innovation. Management Science, 53(7): 1113-26.

Scott, W. R. 2003. Organizations: Rational, natural and open systems. 5th ed. Upper Saddle River, NJ: Prentice Hall.

Shapiro, D. L., Sheppard, B. H., \& Cheraskin, L. 1992. Business on a handshake. Negotiation Journal: 365-77.

Shenkar, O. \& Zeira, Y. 1992. Role conflict and role ambiguity of chief executive officers in international joint ventures. Journal of International Business Studies, 23(1): 55-75.

Sitkin, S. B. \& Bies, R. J. 1993. The legalistic organization: Definitions, dimensions, and dilemmas. Organization Science, 4(3): 345-51.

Sujan, M. 1985. Consumer Knowledge: Effects on Evaluation Strategies Mediating Consumer Judgments. Journal of Consumer Research, 12(1): 31.

Sussman, N. M. 2011. Working Abroad and Expatriate Adjustment: Three Disciplinary Lenses for Exploring the Psychological Transition Cycle of International Employees. Social and Personality Psychology Compass, 5(7): 393-409.

Sytch, M. \& Tatarynowicz, A. 2014. Exploring the locus of invention: The dynamics of network communities and firms' invention productivity. Academy of Management Journal, 57(1): 249-79.

Sytch, M., Tatarynowicz, A., \& Gulati, R. 2012. Toward a Theory of Extended Contact: The Incentives and Opportunities for Bridging Across Network Communities. Organization Science, 23(6): 1658-81.

Tajfel, H. 1969. Cognitive aspects of prejudice. Journal of Social Issues, 25: 79-97.

Teece, D. J. 1986. Profiting from Technological Innovation: Implications for Integration, collaboration, Licensing and Public Policy. Research Policy, 15(6): 285-305.

Terracciano, A. \& McCrae, R. R. 2007. Perceptions of Americans and the Iraq Invasion Implications for Understanding National Character Stereotypes. Journal of cross-cultural psychology, 38(6): 695-710.

Tsai, W. \& Ghoshal, S. 1998. Social capital and value creation: The role of intrafirm networks. Academy of Management Journal, 41(4): 464-78. 
Uzzi, B. 1997. Social structure and competition in interfirm networks: The paradox of embeddedness. Administrative Science Quarterly, 42(1): 35-67.

White, S. 2000. Competition, Capabilities, and the Make, Buy, or Ally Decisions of Chinese State-Owned Firms. Academy of Management Journal, 43(3): 324-41.

Williams, M. 2001. In Whom We Trust: Group Membership as an Affective Context for Trust Development. Academy of Management Review, 26(3): 377-96.

Williamson, O. E. 1975. Markets and hierarchies: Analysis and antitrust implications. New York: The Free Press.

Wong, S. S. \& Boh, W. F. 2010. Leveraging the Ties of Others to Build a Reputation for Trustworthiness Among Peers. Academy of Management Journal, 53(1): 129-48.

Wyer, R. S. \& Carlston, D. E. 1979. Social cognition, inference, and attribution. Hillsdale, N.J. New York: Lawrence Erlbaum Associates.

Zaheer, A., McEvily, B., \& Perrone, V. 1998. Does trust matter? Exploring the effects of interorganizational and interpersonal trust on performance. Organization Science, 9(2): 141-59.

Zaheer, S. \& Zaheer, A. 2006. Trust across Borders. Journal of International Business Studies, 37(1): 21-29.

Zollo, M., Reuer, J. J., \& Singh, H. 2002. Interorganizational routines and performance in strategic alliances. Organization Science, 13(6): 701-13.

Zucker, L. G. 1986. Production of trust: Institutional sources of economic structure, 1840-1920. Research in Organizational Behavior, 8: 53-111. 